\title{
NOTE
}

\section{CRIMINAL REGISTRATION ORDINANCES: POLICE CONTROL OVER POTENTIAL RECIDIVISTS*}

During the past twenty years, the enactment and administration of the body of laws known as "criminal registration ordinances" have introduced an intriguing and important development in the control of criminal activity. In general, these ordinances require certain persons in the jurisdiction who have been convicted of enumerated crimes to register with the local police officials and to furnish them with certain data regarding their prior criminal history and present activities. ${ }^{1}$ In their purpose and scope the ordinances are separate and distinguishable from probation and parole laws. Under the latter, a convicted person undergoes surveillance in lieu of incarceration, ${ }^{2}$ whereas the criminal registration ordinances generally require registration irrespective of the parole, probation or past incarceration of the convicted person. In theory, the probation and parole laws have been devised to rehabilitate the individual, ${ }^{3}$ while criminal registration laws are an attempt to aid law enforcement agencies in the prevention and detection of the individual's recidivistic behavior. The criminal registration laws are also separate and distinct from "workers' registration laws," which require a person to register with local authorities before engaging in enumerated types of employment. ${ }^{4}$ This Note treats workers' registration only to show its conjunctive use with the criminal registration ordinances.

The efficacy and social desirability of criminal registration is a matter of controversy.5 The purpose of this Note is to determine (1) the preva-

* The research for this Note was financed by funds granted to the University of Pennsylvania Law School for studies on Law Enforcement and Individual Liberty. Jacob Kossman, Esq., of the Philadelphia Bar, has established a fund for this purpose in memory of the late Justice Wiley Rutledge.

The Law Review wishes to express its appreciation for the generous cooperation of the various police officials, officers, and others whose assistance was of great value.

1. The registration requirements and process are described more fully in text at note 82 et seq. and text preceding and following note 151 infra.

2. See, e.g., Barnes and Teeters, New Horizons in Criminology 382, 814 (rev. ed. 1949).

3. $I d$. at $373,826-28$.

4. See text at note 23 and note 23 infra.

5. For example, Mr. Buron Fitts, former District Attorney of Los Angeles, California, and co-author of that city's ordinance stated in a letter of January 5, 1954: "I can say that since the day of its enactment to the date of my departure from office the ordinance was indeed effective. It consists of secret information and establishes a file of great use to law enforcement agencies without harm to the individual in view of its secrecy. It has since been amended to provide the inclusion of sex perverts and offenders against children." 
lence of these ordinances; (2) the persons subjected to them; (3) the duties imposed on the persons affected; (4) the resulting penalties or dangers to these persons; (5) the various methods of administering the ordinances; (6) the degree to which the ordinances achieve their purposes; and (7) the constitutionality of the ordinances.

\section{Historical Background}

In the early nineteen-thirties significant segments of the American public became alarmed at an apparently increasing rate of professional criminality. ${ }^{\mathfrak{C}}$ Legislative action to meet the new menace was said to be imperative; ${ }^{7}$ and a federal investigating committee scoured the country for information which could form the basis for a national legislative solution. ${ }^{8}$ In addition, state criminal laws were generally re-examined. In several instances penalties were increased, habitual and multiple offender laws were enacted and other new legislation was passed to meet the criminal

On the other hand, Mr. Leroy J. Contie, Jr., City Solicitor of Canton, Ohio, stated in a letter of November 25, 1953: "We have made two arrests over a period of two years relating to failure to register under our criminal registration ordinance. . . . I, personally, am not in sympathy with our ordinance as it is impossible to administer and it has only been used in isolated cases to eliminate an undesirable individual coming into the community. There are those individuals who label our ordinance as 'Jean Val Jean legislation.' I am of the opinion that even though such legislation may be of value in checking upon hardened criminals, that it works a definite hardship on an individual who has paid his debt to society and is attempting to rehabilitate himself."

These and all other communications cited in this Note were sent to the UNIversity of Pennsylyania Law Review and are on file in Biddle Law Library, University of Pennsylvania Law School.

6. See Hearings Before Subcommittee of the Committee on Commerce pursuant to $S$. Res. 74, 73d Cong., 2 d Sess. 145, 629-33, 155 (1933) ; People v. Stein, 265 Mich. 610, 616, 251 N.W. 788, 790 (1933) (dissenting opinion). It is difficult to determine the validity of the popular belief that professional criminality was increasing and there is some evidence that the total crime rate was actually decreasing during the early thirties. Chicago Police Problems, $25 \mathrm{~J}$. CrIM. L. \& Criminology 168 (1934) (report of the Institute of Public Administration) (two and one-half year downward trend in Chicago crime). See also, Current Note, Baltimore Report, $23 \mathrm{~J}$. CRTM. L. \& CRTMINOLOGY 498 (1932) (number of serious crimes in first quarter of 1932 lower than in any corresponding period since 1924 with exception of 1930); Current Note, Philadelphia Report, 23 J. CRrM. L. \& CrMmINology 499 (1932) (less crime in first quarter of 1932 than in any quarter in 1931).

7. See Hearings, supra note 6 , at 99-100, 117, 136-37, 139, 182, 183, 185.

8. Sen. REs. No. 74, 73d Cong., 1st Sess. (1933), created the committee headed by Senator Copeland.

The extreme proposals offered by witnesses before the Copeland committee serve to illustrate the tenor of the period. For example, there were suggestions for constitutional amendments which would have permitted a national vagrancy act under which the burden would have been upon the accused to prove that he was earning an honest living and which would have sanctioned unlimited search and seizure of anyone reputed to be carrying firearms in violation of the law. Hearings, supra note 6 , at 135,307 . See also Note, Some Recent Methods of Harassing the Habitual Criminal, 16 ST. Lovrs L. REv. 148, 162 (1931), in which it is reported that Wiley B. Rutledge, then Dean of the Washington University School of Law at St. Louis and later a Justice of the United States Supreme Court, advocated the establishment of a commission with certain safeguards having the power to convict persons as public enemies and fix terms of their removal from society without the necessity of a conviction for a specific offense as required at common law. 
activity of that time. ${ }^{9}$ A few of the new laws in effect punished persons for being "criminals." For example, Illinois amended its Vagabond Law to punish persons "reputed to be habitual violators of criminal laws . . ." and "associates, companions, or bodyguards of such persons . . ."; New Jersey, on the other hand, adopted a law to imprison "gangsters," defining gangster as" any unemployed, previously-convicted person "known to be a member of any gang consisting of two or more persons. . . ."11 These statutes, however, were declared unconstitutional. ${ }^{12}$ Some jurisdictions used their existing vagrancy laws to harass the gangsters and racketeers. ${ }^{13}$

This activity formed the background in which the criminal registration ordinances had their inception. ${ }^{14}$ Many felt that these ordinances would be effective because criminals ${ }^{15}$ would be harassed by the information requirements and convictions could be obtained merely by showing presence within the jurisdiction, a criminal record and failure to register. The burden of proving a criminal reputation or no visible means of support, as required by the vagrancy and "gangster" laws, ${ }^{16}$ was no longer an obstacle.

9. See Chamberlain: Criminal Legislation of 1931, 18 A.B.A.J. 167-71, 204-05 (1932) ; Criminal Statutes for 1932, 19 A.B.A.J. 181-85 (1933); Criminal Legislation of 1933, 20 A.B.A.J. 219-21 (1934).

10. IlL. Rev. Stat. c. $38, \S 578$ (1933).

11. LAWS OF NEW JERSEY c. 155, 44 (1934).

12. People v. Belcastro, 356 I11. 144, 190 N.E. 301 (1934); Lanzetta V. New Jersey, 306 U.S. 451 (1939). A similar law in Michigan was held unconstitutional in People v. Licavoli, 264 Mich. 643, 250 N.W. 520 (1933). This law, known as the "public enemy" law provided that: "Any person who engages in an illegal occupation or business . . . shall be deemed a disorderly person. Proof of recent reputation for engaging in an illegal occupation or business shall be prima facie evidence of being engaged in an illegal occupation or business." MTCH. STAT. ANN. $\$ 28.364$ (1938).

13. See Lacey, Vagrancy and Other Crimes of Personal Condition, 66 Harv. L. REv. 1203, 1218 (1953). The activity of the Chicago police in this respect was widely publicized. Note, Some Recent Methods of Harassing The Habitual Criminal, 16 Sr. Lours L. Rev. 148, 153 (1931) ; Note, Use of Vagrancy-type Lawes for Arrest and Detention of Suspicions Persons, 59 Y ALE L.J. 1351 (1950) ;. Crowley, Observations on American Police Systems, 20 J. CRIM. I. \& CRIMINology 167, 169 (1929). Although in many cases these criminals were quite affluent, they still were subjected to arrest as vagrants without visible means of support. The Chicago police attempted to hold one such "vagrant" in $\$ 50,000$ bail but on appeal the Supreme Court of Illinois reduced it to $\$ 5,000$. People ex rel. Sammons v. Snow, 340 I11. 464,173 N.E. 8 (1930). A 1933 newspaper article describes a police raid in New York City in which one Michail Coppola was arrested as a vagrant under $\$ 1722$ of the New York Penal Code. The article states that when the suspect was told of the nature of the charge he withdrew a roll of bills amounting to $\$ 800$ from his pocket and asked, "Did you ever see a vagrant with that much cash?" N.Y. Times, June 13, 1933, p. 40, cols. 5-6. See also statement by Fiorello La Guardia, then Mayor of New York City, in N.Y. Times, April 19, 1939, p. 25, col. 5.

14. Criminal registration ordinances first appeared in the United States in 1933 when Los Angeles (see N.Y. Times, Sept. 13, 1933, p. 20, col. 2), Arcadia and South Gate, California; and Miami Beach and Coral Gables, Florida, enacted their ordinances. See Appendix B infra.

15. A "criminal" or a "convicted person" as used throughout this Note will refer to a person who has previously been convicted of a crime enumerated in a criminal registration ordinance, but who is not necessarily presently engaged in criminal activity.

16. See Lacey, supra note 13 , at 1213. 
The immediate objectives of these ordinances appeared to be the incarceration or expulsion of undesirables, rather than the registration of criminals. ${ }^{17}$ It was believed that the individuals affected would move elsewhere to avoid registration. ${ }^{18}$ However, as more jurisdictions adopted these ordinances, a convicted person would be less able and less likely to escape registration by moving. Therefore, the principal mode of evasion would tend to become a failure to register with the consequent fulfillment of only the incarceration objective. A subordinate objective to incarceration or expulsion was temporary detention. One chief of detectives observed that his force, while not particularly interested in prosecuting non-registrants, is interested in having the ordinance available to hold such individuals temporarily for questioning, and is "very well pleased with the results brought about by the enactment of this Ordinance." 19

Other supporters of the ordinances apparently felt that the registration data would be of substantial practical use to law enforcement agencies in locating and following the activities of probable recidivists. ${ }^{20}$ In fact, universal registration and fingerprinting have been advocated, ${ }^{21}$ though

17. Referring to the adoption of the Los Angeles, California, ordinance, it was reported that: "District Attorney Buron Fitts and Robert P. Stewart, chief deputy district attorney, who framed the legislation, and Chief of Police James Davis, one of its chief supporters, declare, however, that the very fact that dangerous ex-convicts will not register is the strength of the law.

"'In the past,' says Chief Davis, 'after every major crime we have picked up many suspects with criminal records. In some of these cases we have been sure that we had in custody the guilty men, but we often lacked legal proof to convict. Under the new registration laws, each of these men can now be dealt with not for the crime suspected, but for failing to register. . . .

"The police department's gangster detail, The Times [Los Angeles] tells us, reports that Eastern gangsters are leaving the city, and that Los Angeles has been tagged in the underworld as "hot:" The Literary Digest, Sept. 30, 1933, p. 39, cols. $1,2$.

The Birmingham, Alabama, ordinance was expected to result "in an exodus of a great number of known criminals." N.Y. Times, July 4, 1935, p. 16, col. 2.

The objective of having undesirables move to other areas is also achieved in some localities by conditioning probation of persons convicted of violating the ordinance upon their leaving the jurisdiction. See text at and following note 170 infra.

Certain groups who were opposed to the ordinances also assumed that those persons engaged in criminal activity would not register. See Current Note, Criminal Registration Lazv, 27 J. CRIM. L. \& CRIMINology 295, 296 (1936).

18. See note 17 supra.

19. Letter from Dan B. Hudson, Chief of Detectives, Evansville, Indiana (Oct. 31, 1953) (Evansville adopted its ordinance during the early part of 1953). See also statement of James Davis, Chief of Police, Los Angeles, California, quoted in note 17 supra.

20. See letter from Mr. Buron Fitts, supra note 5. See also Criminal Statistics and Identification of Criminals, $19 \mathrm{~J}$. CRIM. L. \& CRIMINologY 36, 43 et seq. (1928).

21. N.Y. Times, Jan. 30, 1934, p. 2, col. 4 (the executive committee of the Chamber of Commerce of New York). See also article by J. Edgar Hoover in 50 Rotarian 16 (Jan. 1937) ; Professor August Vollmer of the University of California, in advocating a universal registration system, listed over one hundred advantages of such a system. Current Note, Universal Registration, $25 \mathrm{~J}$. CrIM. L. \& CrrmINology 650 (1935). See 51 AM. CITY 99 (April 1936) (citing the official publication of the United States Conference of Mayors). In 1941, bills were introduced in the House of Representatives which would have required all residents of the United States over 16 years of age to register and be fingerprinted. Current Note, Bills in Congress re Fingerprinting, 32 J. CrnM. L. \& CRIMINology 656 (1942). Many 
never adopted, ${ }^{22}$ as an aid to law enforcement officials; and many localities require the registration and fingerprinting of certain employees and other segments of society. ${ }^{23}$ To those who advocated universal registration and fingerprinting the criminal registration ordinances were a significant step toward that goal.

Finally, there apparently were a few who were motivated by a belief that any regimentation of the masses, and particularly of those who had previously demonstrated a criminal tendency, was a desirable end in itself. As one Philadelphia detective stated, he favored the criminal registration ordinances because it led the "criminals" to believe that they were under the surveillance of the police department. The registrant's feeling of constant surveillance and obligation to notify the police of any change of address might impose some regimentation upon the criminals. ${ }^{24}$

government officials and other persons suggested some form of universal registration and fingerprinting to the Copeland committee. Hearings, supra note 6 , at 11,171 , 286, 290, 337, 344, 394, 443. In 1935, Mr. J. Edgar Hoover stated that "fingerprinting is of potential value to every citizen. . ." and announced that the FBI would supply local school boards with supplies to fingerprint the students. Hoover, Fingerprinting School Children, 21 ScHOOL LIFE 2 (1935).

22. Although universal registration and fingerprinting laws are not found in the United States, they do exist in South America and Europe. For a complete description of a few of these registration systems and an appreciation of their thoroughness, see 75 Bull. OF THE PAN AM. UNION 374 (1941) (Dominican Republic); White, Indexed Fingers, 2 The INTER-AMrerican 27 (Dec. 1943) (Chile); Kempner, The German National Registration System as Means of Police Control of Population, 36 J. Crim. L. \& Criminology 362 (1946).

23. The Miami Beach, Florida, workers' registration ordinance requires practically every employed person to register within 48 hours of the time of employment and pay a $\$ 1,00$ fee. Lakewood and Atlantic City, New Jersey, require the registration and fingerprinting of non-resident employees; Las Vegas, Nevada, requires the registration of "all employees of gambling houses, taxi drivers, and employees of establishments where alcoholic beverages are sold at retail and served on the premises. ..." Ordinances requiring taxi cab drivers to register with the police and to be fingerprinted, photographed and to furnish information regarding any past criminal record are quite common. Such an ordinance was upheld on its face in Walton v. City of Âtlanta, 181 F.2d 693 (5th Cir.), cert. denied, 340 U.S. 823 (1950). See also Norman v. Las Vegas, 64 Nev. 38, 177 P.2d 442 (1947) (liquor employees' registration ordinance held constitutional). In 1936 Berkeley, California, attempted to fingerprint the city's entire population. See Fingerprints of Fascism, The New Republic, June 10, 1936, p. 118, col. 1.

24. A few instances demonstrated that some people actually feel that the police have them under constant surveillance. In one case a Negro woman came into the Identification Division of the Philadelphia Police Department to report that she was leaving the city for four days to attend her mother's funeral and wanted to notify the police so that she would not be in trouble when she returned. Many registrants are told to keep the police informed of any new adresses, but no cases were observed in which a person reported a new address. One individual reported that he had lost his registration card and had come to the police right away because he did not want to get into trouble.

Those opposed to the ordinance also evidently considered this aspect. "A more important objection ... . is the psychic effect which it has on every man who has committed a crime. It opens up old sores. It re-affirms the conviction which exists in the minds of too many of these people that the police are anxious to get something on them. The fact that this is not so does not matter. The important thing is that this group of individuals feels that it is so." Current Note, Criminal Registration Law, 27 J. CRIM. L. \& CRIMINology 295, 295-96 (1936). 


\section{The Prevalence of Criminal Registration Ordinances}

Of the 246 localities which responded to this survey ${ }^{25}$ forty-seven have criminal registration ordinances. ${ }^{26}$ Analysis of the geographical distribution shows that about $80 \%$ of these localities which have ordinances are situated in five relatively compact regions. ${ }^{27}$ One explanation for this concentration may be that when one locality adopts such an ordinance the surrounding localities usually follow suit. The remaining nine localities which reported ordinances are scattered throughout the United States, but no ordinances were found in the northeast section of the country. Five states have enacted criminal registration statutes, ${ }^{28}$ which are more narrowly drawn than are the local ordinances. Four of these states are located in the five regions in which the local ordinances are concentrated.

\section{The Ordinances Analyzed ${ }^{29}$}

\section{Persons Required to Register}

Conviction Required: Conviction of a crime, rather than mere arrest or indictment, is the requisite for registration liability under all the

25. Questionnaires were sent to 406 cities which were chosen primarily on the basis of population and geographic location, although certain localities were chosen because they were resorts, located near race tracks or near a larger city which had an ordinance. Appendix A more fully describes the scope of this survey.

26. The West Palm Beach, Florida, ordinance was reportedly declared invalid, but details are unavailable. The Tampa, Florida, ordinance expired of its own limitation. See Appendix B infra.

Lexington, Kentucky, reported that it did not have a criminal registration ordinance, "but one is being formulated and is to be incoporated in our forthcoming revised Criminal Code." Letter from E. C. Hale, Chief of Police, Lexington, Kentucky (March 22, 1954). Minneapolis, Minnesota, reported that its city council did not pass a proposed ordinance; Portland, Oregon, reported that it would welcome an ordinance. Fairmount, Minnesota, reported that it is endeavoring to pass such an ordinance.

27. These five regions and the approximate percentage of the 47 ordinances which each region has are as follows: (1) the west coast of California from San Francisco to San Diego-21\%; (2) a belt approximately seventy miles wide and 350 miles long from Cleveland, Ohio, to Evansville, Indiana-19\%; (3) eastern Pennsylvania and New Jersey-19\%; (4) Florida-15\%; and (5) southeastern Minnesota$9 \%$.

28. The five states are: Arizona-Aruz. Code Ann. \$ 43-6117 (Cum. Supp. 1951); California-Cal. Penal Cone $\$ 290$ (Deering 1949); Illinois-Ill. ANN. Stat. c. 38, $\$ 192.29$ et seq. (Smith-Hurd Cum. Supp. 1953); New Jersey-N.J. STAT. ANN. \$2A:169A-1 et seq. (1953); and Florida-Chapter 28470 Laws of Florida, 1953 (applies to counties with populations of 450,000 or more). The previous Florida statute applied to counties with populations of over 150,000 .

29. Of the 47 localities which have criminal registration ordinances, 41 submitted copies of their ordinances to the Law Review for this study. The following analysis is based primarily on a study of these 41 ordinances and the ordinance of Akron, Ohio, although, in certain instances, the statutes of California, Florida, Illinois and Arizona are also considered. Except where otherwise specified, the Camden, New Jersey, ordinance which is discussed throughout this Note is that which was adopted in 1934, as amended in 1935. As of the completion of the writing of this Note, the Camden ordinance was in the process of being amended. 
ordinances. ${ }^{30}$ It is well established in analogous fields that a requirement of a prior "conviction" will be satisfied by judgments resulting from pleas of guilty, ${ }^{31}$ nolo contendere,,$^{32}$ or non vult, ${ }^{33}$ on the other hand, pending appeal ${ }^{34}$ or after reversal ${ }^{35}$ of a trial court's verdict of guilty an individual will not be considered as having been "convicted." Under the criminal registration ordinances, however, it is not clear whether an individual would be deemed a "convicted" person pending appeal or after reversal of his conviction. The lack of clarity in this area can produce unjust applications of the registration requirement. Since most ordinances require registered persons to notify the police of their movements, it is possible that a registered individual, although no longer under the liability to register, must nevertheless continue to observe the requirements of notification because of the lack of a procedure to remove his registration..$^{36}$

Generally, one conviction of any of the enumerated offenses is sufficient to require registration. The only exceptions are the ordinances of

30. The Canton, Ohio, ordinance also provides that any person who "shall have pleaded guilty to" the enumerated offenses shall be required to register. Shaker Heights and Springfield, Ohio, have similar provisions as does the Florida statute, Chapter 28470, Laws of Florida 1953.

31. People v. Dail, 22 Cal.2d 642, 140 P.2d 828 (1943) (statute authorizing impeachment of witness by showing prior conviction); Clinton v. State, $143 \mathrm{Fla}$. 356, 196 So. 684 (1940) (prior offender statute); State v. Stewart, 110 Utah 203, 171 P.2d 383 (1946) (prior offender statute); Schooley v. United States, 4 F.2d 767 (8th Cir. 1925) (judgment must follow the guilty plea for it to be considered a prior conviction within the meaning of multiple offender statutes); People v. Adams, 95 Mich. 541, 55 N.W. 461 (1893) (prior offender statute).

32. United States v. Dasher, 51 F. Supp. 805 (E.D. Pa. 1943) (plea of nolo contendere sufficient to charge accused as second offender under Fair Labor Standards Act) ; State v. Suick, 195 Wis. 175, 217 N.W. 743 (1928) (plea of nolo contendere sufficient to subject defendant to second offender provision). See also Note, 152 A.L.R. 253, 290 (1944).

33. People v. Daiboch, 265 N.Y. 125, 191 N.E. 859 (1934), reversing 240 App. Div. 153, 269 N.Y. Supp. 321 (1st Dep't 1934) (plea of non vult sufficient to subject defendant to second offender provision).

34. The analogous cases in this area involve the multiple offender statutes. Nelson v. State, 116 Neb. 219, 216 N.W. 556 (1927) ; State v. Zounick, 133 Wash. 638, 234 Pac. 659 (1925); McAlester v. State, 16 Okla. Crim. 70, 180 Pac. 718 (1919). See Morse v. State, 63 Okla. Crim. 445, 455, 77 P.2d 757, 762 (1938); Commonwealth v. McDermott, $224 \mathrm{~Pa} .363,365,73$ Atl. 427, 428 (1909) (motion for arrest of judgment pending). Contra: People v. Morlock, 234 Mich. 683, 209 N.W. 110 (1926). See also Note, 5 A.L.R.2d 1092-97 (1949). Where the use of the prior conviction is for impeachment purposes, an individual is considered "convicted" immediately after the verdict of guilty, although an appeal may be taken. People v. Clapp, 67 Cal.App.2d 197, 153 P.2d 758 (1944); Hackett v. Freeman, 103 Iowa 296, 72 N.W. 528 (1897). A conviction which is on appeal is not grounds for divorce. Rivers v. Rivers, 60 Iowa 378, 14 N.W. 774 (1883).

35. Juskulski v. State, 206 Ind. 503, 190 N.E. 423 (1934) (habitual criminal law); People v. Van Zile, 80 Misc. 329, 141 N.Y. Supp. 168 (1913) (use of prior conviction for impeachment purposes); Brittian v. State, 85 Tex. Crim. 491,214 S.W. 351 (1919) (prior conviction provision).

36. In Philadelphia, one man was observed as he requested the officer in charge to cancel his registration. According to the man, he had been advised by his attorney to register after conviction in the trial court, but before an appeal had been taken. On appeal, the conviction was reversed. The officer told the man that he did not have the authority to remove his registration card from the files. Since this was the individual's only "conviction," it would appear that he was $n$ r longer under a liability to register, but, having previously registered, it is probable that he had to continue compliance with the other requirements of the ordinance. 
Lorain, Cincinnati, and Columbus, Ohio, which require two prior felony convictions. An even more satisfactory provision would be one which correlates the multiplicity of prior convictions with the character of offenses committed, but none of the ordinances examined employ such a standard.

Nature of the Crime Previously Committed: Since the apparent objective of the ordinances is to secure the registration of recidivists, one would expect the registration liability to be confined to recidivistic crimes. The state legislation, with the exception of that of Florida, ${ }^{37}$ is focused at specific purportedly recidivistic crimes. California and Arizona require certain sex criminals to register, while Illinois and New Jersey require the registration of narcotic offenders. ${ }^{38}$ However, none of the local ordinances are specifically aimed at recidivistic crimes. For example, Atlantic City and Lakewood, New Jersey, require all persons convicted of any crime to register. Fifteen jurisdictions limit registration to those who have committed felonies, ${ }^{39}$ while a few ordinances limit registration to persons convicted of felonies involving moral turpitude. ${ }^{40}$ Other juris-

37. The present Florida statute requires the registration of persons who have been convicted of a felony. Chapter 28470 , Laws of Florida 1953, $\$ 1$. The original statute, however, provided that any person who had been convicted of a "felony involving moral turpitude" was required to register. Chapter 18107, Laws of Florida 1937, \$2.

38. See note 28 supra. Narcotic offenders are generally recidivistic in that the addict by definition is engaged in a course of repetitious behavior and those engaged in selling narcotics are predominantly either professionals or addicts. But authorities agree that recidivism among sex criminals is negligible. For example, a study of recidivism among sex criminals in New York City shows that: "First offenders commit most sex crimes. . . [O]f sex offenders convicted in the County Courts and the Court of General Sessions [for decade 1930-1939] 61\% had no record. Where sex offenders do have prior criminal records, it is usually for non-sexual crimes. . - Police department fingerprint records disclose that only $7 \%$ of the persons convicted of sex crimes in 1930 were again arrested on charges of sex crime during the period from 1930 to 1941." Mayor's Comamittee For StUdy of SEX OfFENSES 11 (1943). The Commission on the Habitual Sex Offender of the New Jersey State Legislature in 1950 reported that: "Sex offenders have one of the lowest rates as 'repeaters' of all types of crime. . . [A]mong serious crimes homicide alone has a lower rate of recidivism." See TAppan, The Habitual Sex OfFender: Report and Recommendations of the Commission on the Habitual Sex Offender, New Jersey State Iegrslature 14 (1950).

39. Cincinnati, Columbus and Lorain, Ohio; Harrisburg, Pennsylvania; Norfolk, Virginia; Seattle, Washington; Akron, Ohio; Birmingham, Alabama; Fort Lauderdale, Miami, and Miami Beach, Florida; Long Beach, California; Rochester, Minnesota (any crime other than a misdemeanor); St. Paul, Minnesota (any crime other than a misdemeanor); and the Florida state statute.

In New Jersey most crimes are classified as a misdemeanor punishable with up to seven years imprisonment. N.J. STAT. ANN. \$\$ 2A:85-6, 2-A :85-7 (1953); Brown v. State, 62 N.J.L. 666, 42 Atl. 811 (1899). Apparently persons convicted of such misdemeanors in New Jersey would not be required to register under the last nine ordinances listed above, even though such persons may have served a sevenyear term; they would have to register, however, under the first six listed ordinances which have provisions similar to the one found in text at note 49 infra.

40. E.g., Lakeland, Florida, and Hot Springs, Arkansas. These ordinances define a felony involving moral turpitude as "an act of baseness, vileness or depravity in the private and social duties which a man owes to his fellow men or to society in general, contrary to the accepted and customary rule of right and duty between man and man, and shall include among felonies any of the offenses known as grand larceny, grand embezzlement, highway robbery, burglary, arson, rape, kidnapping, murder, theft, wiretapping, and conspiracies involving confidence games." 
dictions avoid a general classification and merely enumerate certain offenses as requiring registration; ${ }^{41}$ however, some of these localities seem completely oblivious of the purported purpose of the ordinances (registering recidivists) by requiring the registration of persons convicted of such nonrepetitious crimes as abduction of a woman for marriage ${ }^{42}$ and miscegenation. ${ }^{43}$ At the same time many localities which enumerate the crimes fail to require the registration of those persons convicted of attempting, ${ }^{44}$ conspiring, ${ }^{45}$ or being an accessory ${ }^{46}$ to the commission of recidivistic crimes. The Philadelphia ordinance not only enumerates specific offenses but also requires the registration of those persons who, within ten years, have either served any part of a sentence in a penitentiary-type penal institution or who have served any part of a sentence of imprisonment for two years or more in any public prison. ${ }^{47}$ The Reno, Nevada, ordinance is unusual in that it not only includes all crimes that would be a felony if committed in Nevada, but also any crime which if committed in Nevada would be a violation of specified sections of the Nevada Criminal Code. ${ }^{48}$

Some of the ordinances provide that a conviction for an offense will impose a liability to register not only (1) if the convicting jurisdiction's designation (e.g., burglary) or classification (e.g., felony) of that offense is the same designation or classification found in the registration ordinance, but (2) if the designation or classification of that offense would have been the same as that of the registration ordinance had it been committed in the registering jurisdiction. ${ }^{49}$ For example, if a person is convicted in State $X$ of an offense which $X$ characterizes as a misdemeanor, but State $Y$ characterizes the same offense as a felony, upon entering a locality in $Y$ which has an ordinance requiring the registration of persons who have been convicted of a felony or of an offense which if committed in State $Y$ would have been a felony, the person will have to register; if, on the other

41. Allentown and Philadelphia, Pennsylvania; Arcadia and South Gate, California; Canton, Shaker Heights and Springfield, Ohio; Coral Gables, Pensacola and St. Petersburg, Florida; Camden, Jersey City, Collingswood and Trenton, New Jersey; and Evansville, Indiana. The following jurisdictions provide for the registration of persons who have been convicted either of a felony or of other enumerated offenses: Las Vegas and Reno, Nevada; Los Angeles, Pasadena, San Diego, and San Jose, California; and Phoenix, Arizona.

42. Los Angeles, California.

43. Pensacola and St. Petersburg, Florida.

44. Arcadia and South Gate, California; Camden and Collingswood, New Jersey; Canton and Springfield, Ohio; Coral Gables and St. Petersburg, Florida; and Evansville, Indiana.

45. Every locality cited in note 44 supra, except Canton and Springfield, Ohio.

46. Every locality cited in note 44 supra, except St. Petersburg, Florida.

47. Apparently this provision was to accomplish the same purpose as the provision cited in text at note 49 infra. Miami Beach, Florida, has a similar provision.

48. These sections include such offenses as constructing a road or railroad through a cemetery, NEv. CoMp. LAws $\$ 10160$ (1929), and selling horsemeat without being able to exhibit the hide of the animal, NEv. CoMp. LAws \$10208 (1929).

49. See, e.g., Las Vegas, Nevada; Harrisburg, Pennsylvania; Pasadena, California; and Phoenix, Arizona. 
hand, $X$ characterizes the offense as a felony, but $Y$ does not, the person still has to register under the ordinance. The purpose of such a provision apparently is to bring all persons who have committed acts which the registering jurisdiction considers dangerous within the scope of its ordinance. A possible interpretation of the Norfolk, Virginia, ordinance would require the registration of anyone who had committed an offense punishable as a felony anyzohere outside the state; this interpretation would make the ordinance of questionable validity since it would appear to place the burden upon the prospective registrant of knowing the law regarding the nature of a felony of every jurisdiction in the world. ${ }^{50}$

Effect of a Pardon for the Prior Offense Upon the Registration Liability: The effect which should be given to a pardon in recidivistorientated legislation, such as criminal registration ordinances, should depend on the basis upon which the pardon was granted. Usually pardons are granted either because of post-conviction discovery of evidence that the individual is innocent, ${ }^{51}$ or because of a quasi-political determination that circumstances warrant a remission of sentence or a restoration of civil rights; ${ }^{52}$ but, unfortunately, most state procedures do not require that the reason or basis upon which a pardon is granted be stated in the pardon records. ${ }^{53}$ When recidivist-orientated statutes are silent, state courts will usually adjudge one a prior offender, regardless of the fact that the previous conviction was pardoned..$^{54}$ The same result would probably follow under the criminal registration ordinances; and, therefore, it would appear that some provision should be made in these ordinances concerning the effect of a pardon.

50. The Norfolk, Virginia, ordinance provides: "Any person who . . has been or may hereafter be convicted of any offense punishable as a felony in the state or elsewhere... shall report. . . "." (Italics added.)

The Jersey City, New Jersey, ordinance bases registration upon having committed either certain enumerated crimes or any crime which would result in loss of suffrage in New Jersey whether the crimes were committed in New Jersey or not.

51. This may be inferred from 28 U.S.C. $\$ \$ 1495,2513$ (1946), which provide that in Court of Claims suits to recover for an unjust conviction a presidential pardon containing a finding that the convicted person did not commit the act charged is equivalent to a judicial finding of innocence. State procedure usually does not afford any judicial procedure for vacating a judgment of guilty after the passage of significant time.

52. "Probably the majority of pardons granted throughout the country are for the purpose of restoring these civil rights after the service of sentence." Weihofen, The Effect of Pardon, 88 U. of PA. L. Rev. 177, 180 (1939). See People v. Biggs, 9 Cal.2d 508, 71 P.2d 214 (1937); Williston, Does a Pardon Blot Out Guilt?, 28 HARV. L. REV. 647 (1915).

53. Weihofen, The Effect of Pardon, 88 U. of PA. L. REv. 177 (1939).

54. In People of State of New York ex rel. Martin Prisament v. Brophy, 287 N.Y. 132, 38 N.E.2d 468 (1941), the defendant was held a prior offender although a presidential pardon stated that: "Whereas it has been made to appear to me that the said ... is innocent of the offense for which he is now being held. . .." The court's rationale was that such an executive determination does not vacate a valid judgment of conviction. See also, Jones v. State, 141 Tex. Crim. 70, 147 S.W.2d 508 (1941), overruling, Scrivoner v. State, 113 Tex. Crim. 194, 20 S.W.2d 416 (1928). Contra: State v. Childers, 197 La. 715, 2 So.2d 189 (1941). 
Approximately one-half of the ordinances provide that a pardoned conviction will not create registration liability, ${ }^{55}$ but even these do not consider the basis upon which the pardon was granted. The remaining ordinances do not deal with the problem of pardoned convictions. ${ }^{\tilde{6} 6}$ The Pasadena, California, ordinance has a slight variation which provides that any person, except a drug addict, who has at any time been placed on probation and whose conviction has been set aside, is not deemed a convicted person. ${ }^{57}$ Although the Philadelphia ordinance provides that one pardoned by competent legal authority need not register, it fails to consider the effect on this provision of a Pennsylvania statute which states that the completion of any sentence "shall have the like effects and consequences as a pardon by the governor. . . ." 58 This statute was repealed in $1939^{59}$ and there is authority to the effect that the statute will apply only to those who have completed their sentences prior to repeal. ${ }^{60}$ Nevertheless, it is quite possible that if persons charged with violating the Philadelphia ordinance had had proper counsel, the provisions of this statute might have been utilized in order to relieve many of the defendants of the registration liability. It is also likely that one convicted in Nebraska and granted a discharge warrant need not register under the ordinances which exclude pardoned convictions, since such a warrant granted on expiration of sentence restores civil rights in the same manner as does a pardon. ${ }^{61}$

Effect Given to Parole, Probation, and Suspended Sentence: The rehabilitative aims of parole, probation, and suspended sentence ${ }^{62}$ generally are not considered or reflected in the criminal registration ordinances; for only a few of them provide that persons on parole or probation, and

55. E.g., Akron, Ohio; Arcadia, California; Atlantic City, New Jersey; Coral Gables, Florida; Evansville, Indiana; Tulsa, Oklahoma; and Philadelphia, Pennsylvania.

56. The Birmingham, Alabama, and Hot Springs, Arkansas, ordinances exempt those who have had their civil rights restored to them by competent legal authority. The Reno, Nevada, ordinance provides that one whose conviction has been set aside in a manner provided by law shall not be considered a convicted person. It is not clear whether this provision applies to pardons or convictions set aside on appeal. See text at note 34 and note 34 supra. The Los Angeles, California, ordinance has a provision similar to that of Reno, but it does not exempt persons who have been convicted of certain sex crimes whose "conviction has been set aside at the termination of probation, and in connection therewith. . .."

57. The Las Vegas, Nevada; Phoenix, Arizona; and San Jose, California, ordinances have similar provisions. See also text at note 63 et seq. infra.

58. PA. STAt. ANN. tit. 19, §893 (Purdon 1930). In Perkins v. United States, 99 F.2d 255 (3d Cir. 1938), it was held that on the basis of Pennsylvania cases this legislative pardon is equivalent to the usual executive pardon.

59. PA. Stat. AnN. tit. 18, § 5201 (Purdon 1939).

60. In United States ex rel. Forino v. Garfinkel, 166 F.2d 887 (3d Cir. 1948), it was held that the statute would not apply to a convict whose sentence did not expire until after the repeal, even though the conviction and part of the prison term had occurred before the repeal. The district court in the same case had held that the repeal would be ex post facto legislation if held to apply to one who had committed a crime prior to the repeal, because it changed the penalty. $69 \mathrm{~F}$. Supp. 846 (W.D. Pa. 1947).

61. NEB. Rev. Stat. §29-2634 (1948). 1951).

62. See Barnes AND TeEters, New Horizons in CrIminology 758 (2d ed. 
persons who have completed parole or probation periods without revocation, need not register. ${ }^{63}$ These provisions are consistent with the attempts to rehabilitate the parolee or anyone on probation. However, no ordinance was found which specifically excluded persons serving a suspended sentence from the registration liability. The Evansville, Indiana, ordinance, which requires registration -only if a conviction is followed by a sentence to serve a term in any state or federal penitentiary, may exclude offenders who have been given a suspended sentence. Those persons who have received a suspended sentence or have been placed on probation may not be required to register even under the ordinances which have no specific provision concerning such individuals, since it might be held that a conviction followed by probation or a suspended sentence does not have the essential finality which is necessary to impose the registration liability. ${ }^{64}$

All the criminal registration ordinances should contain provisions which are consistent with the rehabilitative efforts of persons on parole, probation or suspended sentence. The framing of these provisions should involve the weighing of various factors, such as: (1) whether the person has indicated criminal tendencies prior to the crime for which he has received a suspended sentence or is now on parole or probation; (2) whether the amount of surveillance the person is under during this period would tend to lessen the need for registration; (3) the degree of conflict between the rehabilitative attempts of parole, probation, and suspended sentence and the harassment of criminal registration ordinances; and (4) the conflict between the aim of parole, probation and suspended sentence to minimize the stigma of criminal conviction ${ }^{65}$ and the imposition by the ordinances of an additional stigma on the convicted person.

63. The South Gate, California, ordinance provides: "That nothing in this ordinance shall be deemed or constructed to apply to any person . . . who is or shall be on parole or probation under the laws of the state of California, or whose parole or probation period under the laws of the state of California shall have expired without any revocation of such parole or probation having been made." Other localities have similar provisions with some variation: Arcadia, California-same as South Gate; Collingswood, New Jersey-same as South Gate except that parole or probation must be under New Jersey law; Louisville, Kentucky-same as South Gate except that parole or probation must be under Kentucky law; Tulsa, Oklahoma-same as South Gate except that parole or probation must be under Oklahoma or United States law; Pensacola and Miami Beach, Florida-presently on parole or probation under the law of any state; Evansville, Indiana-presently on probation under Indiana law. The San Diego, California, ordinance excepts from registration only those persons on probation or whose probation has been completed without revocation, but this exception does not apply to sex criminals. Camden, New Jersey, had an ordinance which contained a provision similar to that of South Gate but Camden Ordinance No. 519, adopted Jan. 24, 1935, amended the original ordinance in order to omit the probation and parole exceptions.

64. Some courts, in the absence of a statute specifically governing the matter, have come to this result when interpreting multiple offender statutes. See People ex rel. Marcley v. Lawes, 254 N.Y. 249, 172 N.E. 487 (1930); Fetters v. State, 108 Tex. Crim. 282, 1 S.W.2d 312 (1927); Commonwealth ex rel. Farrell v. Ashe, 93 Pitts. L.J. 293 (Pa. 1945). Contra: People v. Rave, 364 I1l. 72, 3 N.E.2d 972 (1936). See also Note, 5 A.L.R.2d 1086-92 (1949). 1951).

65. See Barnes and Teeters, New Horizons in Criminology 762 (2d ed. 
The Treatment of Juveniles Under the Ordinances: In many states the treatment of juveniles involved in unlawful conduct deviates from the traditional treatment of adult criminals. The policy of protecting juveniles from the stigma of a criminal record has been generally reflected in the juvenile court acts, ${ }^{66}$ wherein various types of anti-social behavior are known as delinquencies rather than crimes. The offenders are treated by the state as its wards rather than its prisoners; the records are usually confidential and in many states fingerprinting is forbidden. This modern policy, however, is not considered in the criminal registration ordinances. Only the Jersey City, New Jersey, ordinance deals with the problem, but it reaches a result contrary to the modern trend by requiring the registration of any person who, while a juvenile, committed an offense which would require registration if it had been committed by a person not a juvenile. ${ }^{67}$ The balance of the ordinances have no specific provision concerning juvenile offenders. However, since most of these ordinances provide that persons convicted of a crime must register, no registration would be required if the convicting jurisdiction treated the juvenile's offense as a delinquency and not a crime; but, under the ordinances requiring registration if the offense would have been a "crime" if committed in the registering jurisdiction, ${ }^{68}$ a juvenile offender would escape registration only if both the convicting and registering jurisdictions termed the offense a delinquency. Thus, the registration liability is dependent not upon the juvenile's criminal propensities, but upon the manner in which the various jurisdictions classify his anti-social behavior.

The Effect Given to Time Elapsed Since Conviction or Release from Penal Servitude: After a convicted person has completed his punishment, the likelihood that he is rehabilitated should vary directly with the amount of time elapsed in which he has refrained from subsequent unlawful conduct. Therefore, it appears that convicted persons who indicate their rehabilitation by a long period of constant lawful conduct should be exempt from registration liability. Although some of the ordinances place no temporal limitation on a person's liability to register, ${ }^{69}$ the more "enlightened" ones do contain various formulae for temporal exemptions. Under many of these ordinances a person must register only if he enters the jurisdiction within the limitation period, usually five to ten years. ${ }^{70}$

66. See Waybright, A Proposed Juvenile Court Act for Florida, 4 U. of FLA. L. Rev. 16 (1951) ; Note, Disposition of the Youthful Offender, 47 Northwestern L. Rev. 224 (1952).

67. The Jersey City, New Jersey, ordinance defines "crime" as: “. . (7) Unlawful commission by a juvenile of any act which would constitute any of the foregoing violations if done by a person not a juvenile wherever committed in the territorial jurisdiction of the United States or of any State."

68. See text at note 49 and note 49 supra.

69. Atlantic City and Jersey City, New Jersey; Birmingham, Alabama; Fort Lauderdale, Florida; Reno, Nevada; and Phoenix, Arizona (except that drug addicts need register only if they have been convicted or adjudged such since Jan. 7, 1936).

70. E.g., Akron, Ohio (ten years); Lakewood, New Jersey (ten years); Philadelphia (ten years); San Diego, California (ten years); St. Petersburg, Florida 
This period normally commences after conviction, although in some cases it commences after release from imprisonment. ${ }^{71}$ Other ordinances specify that a person convicted prior to a certain date does not have to register. ${ }^{\mathbf{2}}$ The most surprising temporal limitation provisions, found in eight of the ordinances, ${ }^{73}$ apply the registration liability only to those persons convicted of crimes a number of years prior to the effective dates of the ordinances; but no provisions are made for registering persons convicted after the effective dates. ${ }^{74}$ For example, the Camden, New Jersey, ordinance states: "Every person who has been convicted in any Federal Court or the court of any state within ten years prior to the effective date of this ordinance . . ." must register. Therefore, it would appear that one need register only if he were convicted of an offense between June 28,1924 , and the effective date of the Camden ordinance-June $28,1934 .{ }^{75}$ The most probable explanations for these provisions are careless drafting and copying of other ordinances.

Upon close analysis of even the more enlightened ordinances, it becomes evident that the temporal limitation provisions were not carefully formulated. For instance, none of them provide for a limitation after a person has registered; and therefore, once a person has registered he must comply with the requirements of the ordinance for the rest of his life,

(ten years); Lorain and Cincinnati, Ohio (five years); Columbus, Ohio (two offenses which must occur within ten years of entrance into the city). Although Hot Springs, Arkansas, and Lakeland, Florida, have a "three years since conviction" limitation, it is applied only to persons who were residents at the time of the adoption of the ordinance.

71. There is little rational basis for using the date of conviction as the starting point. For example, under the Cincinnati, Ohio, ordinance, which requires registration of persons convicted within five years of entry into the city, a person entering the city after completing any sentence of more than five years would not have to register. The Evansville, Indiana, ordinance avoids this difficulty by providing for the registration of those persons "whose release from such penitentiary has been less than five (5) years prior to his or her coming into this city from any point outside thereof. . ." Another locality having a similar provision is Long. Beach, California (seven years from conviction if not imprisoned or seven years since release from prison by discharge or parole).

72. E.g., Pasadena, California (applies only if conviction subsequent to January 1,1921 , or, if conviction prior to that date, term of imprisonment, period of punishment or sentence, term of parole or probationary period did not or will not expire until after that date); Los Angeles, California, requires the registration of all persons who were convicted of the enumerated crimes subsequent to January 1, 1921, except that persons convicted of offenses under $\$ 647(5)$ (vagrancy provision) of the California Penal Code, or if convicted outside of California of any offense which, if committed in California, would have been punishable under that section need only register if so convicted after January 1, 1945; San Jose, California, has a provision somewhat similar to that of Los Angeles.

73. Camden, Collingswood, and Trenton, New Jersey; Coral Gables and Pensacola, Florida; Arcadia and South Gate, California; and Louisville, Kentucky.

74. Some ordinances, however, do provide for the registration of persons convicted before and after the effective date of the ordinance. E.g., Harrisburg, Pennsylvania; Norfolk, Virginia; and Rochester, New York.

75. Recently an individual, who had been convicted subsequent to June 28, 1934, was charged with violating the Camden ordinance and his contention that the ordinance was not applicable to him was upheld. As a result, the ordinance, at the completion of this writing, is in the process of being amended in order to overcome this difficulty. See Philadelphia Inquirer (N.J. ed.), Sept. 10, 1954, p. 25, col. 8. 
even if he never becomes involved in criminality again. Since there are exemptions for persons entering the jurisdiction after the required time following conviction has elapsed, the same policy should be applied to registrants who desist from further criminality. A possible solution would be to require all persons subject to an ordinance to remain registered only throughout the limitation period. For example, a person entering a jurisdiction two years before his limitation period has expired would be required to register and fulfill the other obligations of the ordinance only for the remaining two years.

Dependence of Registration Obligation Upon Residence or Presence in the Jurisdiction: The ordinances generally apply to both residents and those in transit through the city. A number of these ordinances require a convicted person to register within a specified time after entering the locality ; ${ }^{76}$ this period varies from Philadelphia's six hours to Long Beach, California's thirty days. ${ }^{77}$ Some of the ordinances which require only a resident to register define the term resident to make it applicable to persons who remain within the jurisdiction more than twenty-four hours and maintain sleeping quarters there. ${ }^{78}$ In addition to its other provisions which impose registration liability, the Pasadena, California, ordinance provides that any convicted person who "comes into or is within the City limits . . . on five (5) occasions or more, during any thirty (30) day period," must register immediately on entering the fifth time. ${ }^{79}$ The reason for such a provision would seem to be that it requires registration of persons such as drug peddlers and gambling house runners who frequently enter the city but remain there a very short time on each occasion. The Jersey City, New Jersey, ordinance provides that any convicted person who comes into the city with intent to remain five days or more, or for the purpose of seeking or engaging in employment, must register immediately, provided that anyone not having the required intent at the

76. Atlantic City, New Jersey, requires registration immediately upon entering the city. The proposed amendment to the Camden, New Jersey, ordinance has a similar provision. According to a newspaper report, one Camden official stated that this provision ". . . would empower Camden city police to pick up ex-convicts who are simply riding through the city on their way to the shore. Asked if he didn't think such a law was a little harsh, he replied: 'It may be harsh, but that's the way we want it." 'Philadelphia Inquirer (N.J. ed.), Sept. 10, 1954, p. 25, col. 8.

77. Camden, Collingswood, Trenton and Lakewood, New Jersey; Cincinnati, Columbus and Lorain, Ohio; and Evansville, Indiana, provide for registration within 24 hours. Arcadia, San Diego and South Gate, California; Coral Gables, Miami Beach, Pensacola and St. Petersburg, Florida; Canton, Ohio; Louisville, Kentucky; and Seattle, Washington provide for registration within 48 hours. Harrisburg, Pennsylvania; Phoneix, Arizona; and Pasadena and San Jose, California, provide that every convicted person "who enters and remains in the city of ... for twenty-four hours, shall within three hours after the expiration of such twentyfour hour period furnish to the Chief of Police. . . ."

78. Lakeland and Miami, Florida; Birmingham, Alabama; and Hot Springs, Arkansas. The Fort Lauderdale, Florida, ordinance defines resident so as to make it apply to persons who remain within the city for twelve hours.

79. A similar provision is found in the following ordinances: Los Angeles and San Jose, California; Phoenix, Arizona; and Reno, Nevada. 
time of entry who remains for five days must register immediately on the expiration of the five days. ${ }^{80}$ Almost every ordinance makes some provision for the registration of those convicted persons who are within the jurisdiction on the effective date of the ordinance. ${ }^{81}$

\section{The Requirements of Registration}

The registration requirements imposed by the various ordinances follow the same general pattern. Usually, the person must register with the chief of police or some person appointed by him to keep the registration records. Almost every ordinance has a provision permitting the registering authority to take fingerprints and photographs. ${ }^{82}$ All the ordinances require the registrant to supply the police with certain information which must be given either under oath ${ }^{85}$ or in the form of a signed statement. ${ }^{84}$ A typical provision as to the information which must be furnished is found in the Camden, New Jersey, ordinance:

"[A convicted person] ... shall furnish ... the true name of such person and each other name or alias by which such person is or has been known, a full and complete description of himself, the place of his birth and present residence, the name or designation of the crime or crimes hereinabove in this section enumerated of which he shall have been convicted, together with the name of the place where each such crime or crimes was or were committed, the name under which he was convicted and the date of the conviction thereof, the name if any, and the location of each prison, reformatory or other penal institution in which he shall have been confined as punishment therefor, together with the location or address of his residence, stopping place, or living quarters when so convicted, and each one thereof, if any, and/or the address or location of his intended residence, stopping place, or living quarters in this City, and each one thereof, with a description of the character of each such place, whether an hotel, apartment house, dwelling, or otherwise, giving the street number thereof, if any, or such description of the address or location thereof as will so identify the same as to make it possible of location, and the length of time for which he expects or intends to reside within the territorial boundaries of this city."

80. Rochester and St. Paul, Minnesota, require registration of those who come into the city with intent to remain for 24 hours or longer, but provide that everyone must register within 48 hours of entry.

81. However, the wording of the Akron, Ohio, ordinance would seem to exempt those in Akron when the ordinance was enacted and who remain in the city thereafter.

82. The following localities make no such provision: Hot Springs, Arkansas; Lakeland, Florida; and Louisville, Kentucky. While the Miami, Florida, ordinance makes no provision for fingerprinting and photographing, the police do take them.

83. Atlantic City and Lakewood, New Jersey; Fort Lauderdale, Lakeland and Miami, Florida; Allentown and Philadelphia, Pennsylvania; Birmingham, Alabama; and Hot Springs, Arkansas.

84. Thirty-three localities require signed statements. 
About twenty other localities have somewhat similar provisions, and approximately seventeen vary only in that they require a listing of all crimes previously committed rather than just those which would be the basis of the registration liability. The Atlantic City, New Jersey, ordinance not only contains most of the requirements of the Camden ordinance, but also requires information regarding the last place of abode before entering the city, whether the registrant is an alien or citizen, and, if a naturalized citizen, the date and place of naturalization. ${ }^{85}$ Nearly all the ordinances provide that any person who fails to furnish the information required or who furnishes false, untrue, or misleading information is subject to the penalties provided for failing to register. ${ }^{86}$

These information requirements are perhaps unnecessarily excessive, since, in most cases, the local police obtain sufficient information from the FBI and the state identification bureaus after the registrant's fingerprint cards are processed. ${ }^{87}$ Furthermore, it is doubtful that many of the registrants are capable of furnishing all the required detail. ${ }^{88}$ These extensive information requirements probably exist because the ordinances arose in the early thirties when the data obtainable by fingerprint processing was significantly less than it is today.

\section{Obligations of Registered Persons}

Once registered, a person is subject to additional obligations under the ordinances. ${ }^{89}$ Almost every ordinance requires the registrant to notify the registering authority of all changes of address. Although most ordinances give the registrant between twelve and forty-eight hours to make such notification, the Jersey City, New Jersey, ordinance requires that it be given "immediately." The Philadelphia ordinance requires, in addition to notification of change of address, that "any person removing from the City having once registered with the Bureau shall notify the Superintendent of Police of such removal before leaving the city." Since the Philadelphia ordinance, like most of the other ordinances, provides that

85. Some variations which are found in one or more localities include: the sentence imposed for every crime committed (e.g.; Atlantic City, New Jersey); ". . the addresses of his or her residence, or living quarters, in all other cities, and the address of his or her present or intended residence or living quarters, in all other cities. . .", date crime was committed, "... length of time he or she intends to reside in this city or in any other to which he or she plans to go. . . " (Evansville, Indiana); whether sentence was complied with, and to what extent, or whether commuted and whether the person has been paroled (e.g., Allentown, Pennsylvania). Quite a few of the ordinances also provide that the registrant shall supply other relevant information as the Chief of Police may require (e.g., Harrisburg and Allentown, Pennsylvania).

86. See text at note 107 et seq. infra. for discussion of the penalties imposed under the ordinances.

87. See text at and following note 154 infra.

88. See text following note 152 infra.

89. The distinction between a person required to register and a "registered person" becomes important in this area because the ordinances usually speak of these obligations in terms of the latter expression. See text at note 36 and note 36 supra. 
failure to furnish any report required by the ordinance shall be subject to the same penalty as failure to register ${ }^{80}$ it would appear that a person would be subject to arrest under the ordinance for leaving the city without having first notified the police.

Another provision, found in only a few of the ordinances, ${ }^{91}$ requires the registrants to carry special cards identifying them as "convicted persons," and provides that failure to carry the card is a violation of the ordinance equal to that of failure to register. ${ }^{92}$ Even though the Philadelphia ordinance does not have such a provision, the city police issue a similar card to each registrant. A statement that the card must be carried at all times is printed on the back of each card. ${ }^{93}$ The police, on the basis of this statement, have charged many persons with a violation of the ordinance for not having the card in their possession. ${ }^{94}$

Provisions for carrying identification cards are found in municipal workers' registration laws and in various state laws, including those dealing with the right to operate a motor vehicle or engage in an occupation. In these situations, such provisions have operative utility in that they enable the enforcement authority, upon observing an individual engaging in a particular activity, to determine immediately whether he is authorized to do so. A similar provision in the Selective Service Act Regulations ${ }^{95}$ helps enforcement officials to determine if a person within the proper age bracket is in violation of the Act. However, it is difficult to see how the card-carrying provision in the criminal registration ordinances is useful in effectuating the purposes of the ordinances. It cannot be determined that a person is in violation of the ordinance because he does not have a registration card, since his record must first be inspected in the police file. This inspection would also disclose whether or not the person is registered.

90. See text at note 86 supra.

91. Camden, Collingswood, Lakewood, Trenton and Atlantic City, New Jersey; and Birmingham, Alabama. Such provisions are also found in the Illinois and New Jersey drug addict registration laws. ILL. ANN. STAT. c. 38, \$192.31 (Smith-Hurd Cum. Supp. 1953); N.J. Star. ANN. §2A:169A-2(4) (1953).

92. For example, the Camden, New Jersey, ordinance provides that: "Every person so registered shall be given a card of identification by the Chief of Police, to which shall be annexed a copy of his photograph. There shall also be written on such card his registry number, the date thereof and the date or length of his proposed stay in this City, and such other data as the Chief of Police may deem necessary. Every such person so registered shall carry with him such card of identification and any failure to have or present the same when requested by any police officer shall be deemed a violation of this ordinance."

93. The Allentown, Pennsylvania, police also issue a "Civilian Identification Card" although it is not mandatory under their ordinance. Apparently, criminals are distinguished from other registrants by the typewritten notation "(Registered)" which appears on the cards. The California Sex Criminal Registration statute does not provide for an identification card, but the registration form contains a perforated slip which is given to the registrant and which is labelled a "Registration Receipt." Samples of these cards are on file in Biddle Law Library, University of Pennsylvania Law School.

94. This matter is more thoroughly discussed in the section of the Note dealing with the practices under the ordinances. See particularly text preceding note 141 infra.

95. 32 Code Fed. ReGS. §1617.1 (1951). 
Therefore, the utility of the provision is limited. It would appear that the purposes behind the provision are to increase the difficulty of complying with the ordinances ${ }^{96}$ and to advise law enforcement officers that a particular individual is an ex-convict and therefore "police-bait." 97 Indeed, it is because of this latter effect that many registrants will not carry the card, even when they believe it is required under the ordinances.

Provisions that supposedly dangerous persons must carry identification cards are not new in the United States. In several instances, the Federal Government has imposed such requirements on aliens, ${ }^{98}$ and at one time Pennsylvania made a similar attempt.90 Under the Pennsylvania Act the alien registered once a year, paid a one-dollar fee, and received an alien registration card. The alien was required to carry the identification card at all times, display it to any police officer or agent of the Department of Labor and Industry who demanded it, and show it in order to register a motor vehicle or obtain a driver's license.

These card-carrying provisions have not been too well received. In considering the validity of the Pennsylvania Act, the majority opinion of the United States Supreme Court stated, as dictum:

"The requirement that cards be carried and exhibited has always been regarded as one of the most objectionable features of proposed registration systems, for it is thought to be a feature that best leads itself to tyranny and intimidation." 100

96. "It [the Camden criminal registration ordinance] has, however, this advantage. . . . If he [the ex-convict] is seized in a raid and cannot show a registration card he can be taken before a police judge and sentenced immediately to a ninety-day jail term or fined $\$ 200 . " ~ N . Y$. Times, July 15, 1934, $\$ 4$, p. 7 , col. 4.

97. Interviews with various detectives in Philadelphia indicated that if an individual carrying a criminal registration card is found in a neighborhood in which a crime has been committed, or is observed under other suspicious circumstances, he is more likely to be detained for investigation than an individual not carrying such a card. In addition, policemen are sometimes more critical in watching an individual on the street if they previously have discovered that he is carrying a criminal registration card.

98. See the Alien Act of 1798, 1 STAT. 577 (1798), (aliens found not to be dangerous given licenses to remain in country); the Act of May 5, 1892, 27 STAT. 25 (1892) (Chinese laborers required to obtain certificates of residence; held valid in Fong Yue Ting v. United States, 149 U.S. 698 (1893)).

On July 1, 1928, while Congress was recessed, Secretary of Labor Davis issued "General Order 106." Representative Cellar stated: "In effect that order provides for a sort of registration of aliens. . . .

". . .

"But here is the real vice of the situation and the core of the difficulty: "the admitted alien,' as the order states, 'should be cautioned to present it for inspection if and when subsequently requested so to do by an officer of the Immigration Service.'" 70 CoNG. REC. 189, 190 (1928).

99. Pa. Stat. Ann. tit. 35, \$\$1801-06 (Purdon 1939). For a discussion of similar statutes of other states see Hines v. Davidowitz, 312 U.S. 52, 61 n.8 (1941).

100. Hines v. Davidowitz, 312 U.S. 52, 71 n.3 (1941). The Court declared the Act invalid because Congress had occupied the entire field in the Federal Alien Registration Act. Thus, the Court did not consider the possible unconstitutionality of the card-carrying provision. However, the Court stated that opposition to these registration laws was based on beliefs that the provisions ". . . were at war with the fundamental principles of our free government, in that they would bring about 
Congress, in the process of enacting the Alien Registration Law, ${ }^{101}$ considered the desirability of a card-carrying provision, ${ }^{102}$ but did not include it in the final legislation. However, the strong objections to such provisions have evidently decreased, because the Immigration and Nationality Revision Act of 1952 requires an alien over eighteen years of age to carry a registration card at all times. ${ }^{103}$ The Senate report on the bill indicates that the card-carrying provision was the most significant change relating to the registration of aliens. ${ }^{104}$ The same tendency is being manifested in the state legislatures, as both the Illinois and New Jersey drug addict registration statutes, enacted in 1953, contain such provisions. ${ }^{105}$

Considering the Supreme Court's dictum in the Pennsylvania Act case, and the inability of a card-carrying provision to help effectuate the purposes of the criminal registration ordinances, it is questionable whether the Court would uphold such a provision under the Fourteenth Amendment. ${ }^{106}$

\section{Penalties Imposed for Violating the Ordinances}

Generally, the penalties imposed under the ordinances are the maximum ones permitted by the various enabling acts under which the criminal registration ordinances were enacted. ${ }^{107}$ The Akron, Ohio, ordinance, for example, provides for a fine of five hundred dollars or imprisonment for six months in the county jail, or both. ${ }^{10 s}$ Such extreme penalties are not at all unusual, ${ }^{109}$ although they seem to be much greater than neces-

unnecessary and irritating restrictions upon personal liberties of the individual, and would subject aliens to a system of indiscriminate questioning similar to the espionage systems existing in other lands." Id. at 71 .

101. 54 Stat. 673 (1940), 8 U.S.C. $\$ 451$ et seq. (1942).

102. H.R. 9101 and H.R. 9147, 71st Cong., 2d Sess. (1929); 72 Cong. Rec. 3886 (1930). See also Hines v. Davidowitz, 312 U.S. 52, 71 n.32 (1941). During consideration of the Alien Registration Bill it was thought by many that the provision that a card be carried was the most objectionable feature of the proposed law. See 72 Cong. Rec. 3886 et seq. (1930).

103. 66 Stat. 224 (1952), 8 U.S.C. $\$ 1304($ e) (Supp. 1952). Prior to this act, an alien was required only to notify the Immigration Bureau of his current residence.

104. Sen. Rep. No. 1137, 82d Cong., 2d Sess. 35 (1952).

105. See note 91 supra.

106. See text at note 199 et seq. infra for a discussion of the due process clause of the Fourteenth Amendment.

107. Compare the penalties imposed by the ordinances as described in note 109 infra with the maximum penalty permitted under the enabling acts of the following states: Minnesota- $\$ 100$ or three months, Minn. STAt. ANN. $\$ \S 412.19(26), 411.78$ (West 1947); Nevada-no fine in excess of $\$ 500$, no term of imprisonment more than six months, NEv. CoMP. LAws $\$ 1231$ (1930); Indiana- $\$ 300$ or six months, IND. STAT. ANN. \$48-1407 (Burns 1950); Florida-\$500 and sixty days, Fla. Stat. ANN. \$165.19 (1943); Ohio- \$500 and/or six months, OHIo GeN. CODE, $\$ 3628$ (1938); New Jersey- $\$ 200$ and/or ninety days, N.J. STAт. ANN. $\S 40: 49-5$ (1953).

108. Other localities having the same penalty include: Pasadena and San Jose, California; Shaker Heights and Springfield, Ohio; and Las Vegas, Nevada.

109. The ordinances imposing the maximum penalty allowed under the enabling acts and the amounts thereof include: $\$ 500$ and/or 90 days-Lorain, Columbus and Cincinnati, Ohio; $\$ 500$ and/or six months-Las Vegas, Nevada; $\$ 500$ and/or sixty days-Coral Gables and Pensacola, Florida; $\$ 300$ and/or 180 days-Evansville, 
sary to insure compliance with the ordinances. Philadelphia, which apparently has a very high rate of compliance, ${ }^{110}$ has a penalty of only one hundred dollars fine or thirty days in the county jail in default thereof. ${ }^{111}$ The penalty imposed by this ordinance, however, is the heaviest that can be imposed under the Pennsylvania enabling statute. ${ }^{112}$ One of the ordinances provides only that any violation is a misdemeanor, ${ }^{113}$ thus permitting the application of the general statutory punishment for misdemeanors. ${ }^{114}$ Since many ordinances require that certain information be given under oath, ${ }^{115}$ it is possible that a registrant who provides false information will be in violation of the applicable state statute penalizing perjury. ${ }^{116}$

Quite a few of the ordinances provide that each day during which a violation of the ordinance continues is a separate violation. ${ }^{117}$ The enforcement of such a provision might make the punishment for failure to

Indiana; $\$ 300$ and/or three months-Arcadia and South Gate, California; and Seattle, Washington; $\$ 200$ and/or 90 days-Atlantic City, Camden, Collingswood, Jersey City, Lakewood and Trenton, New Jersey (Atlantic City, Collingswood and Lakewood also provide for an additional 90 days imprisonment in default of fine); $\$ 100$ or 90 days-Rochester and St. Paul, Minnesota.

110. See Appendix C infra.

111. The Philadelphia ordinance provides: "Any person required by the terms of this ordinance to register, and failing to do so, or who .... in any other manner violates the terms and provisions of this ordinance . . . shall be subject to a fine of one-hundred dollars $(\$ 100)$ for each offense, recoverable with costs, together with judgment of imprisonment not exceeding thirty days if the amount of said fine and costs shall not be paid into the court imposing the fine within ten days from the date of the imposition thereof, as provided for in the act of March 25, 1929, P.L. 66." There is some question as to whether the defendant, after conviction, will be discharged for ten days pending payment of the fine, even in a case in which it is obvious that such payment is impossible. The Philadelphia practice appears to be to release the prisoner for the ten days only if he is actually aware of his rights. From the context of the ordinance, it is obvious that many undesirables will either leave town or make it difficult for the police to recapture them, and a few police officers thought that the ten-day provision reduced the effectiveness of the ordinance. Harrisburg, Pennsylvania, has a similar provision except that it provides for a penalty of $\$ 100$ or 90 days in default thereof.

112. Pa. Stat. Ann. tit. 53, $\$ 3451$ (Purdon 1931). The wording of the Philadelphia ordinance is exactly the same as that of this statute. It is interesting to note that in Pennsylvania a municipality smaller than Philadelphia is permitted to impose a larger penalty for violation of its criminal registration ordinance. See PA. Stat. Ann. tit. 53, § 12198-2403(60) (Purdon Supp. 1952).

113. Hot Springs, Arkansas.

114. Some ordinances merely declare registration to be required and prohibit false registration without providing any penalty. See, e.g. Phoenix, Arizona; Reno, Nevada; St. Petersburg, Florida; and San Diego, California. Under such circumstances, the penalty for violating the ordinance would probably be provided for in a general penalty section of the municipal code. See, e.g., SAN Diego Municipal CODE $\$ 11.12$ (1952).

115. See note 83 supra.

116. See, e.g. Cal. PENal Code $\$ \$ 118,125$ (1949) . (perjury); Fla. Stat. ANN. $\$ 837.01$ (1944) (perjury otherwise than in judicial proceedings); N.J. STAT. ANN. \$2A:131-4 (1953) (false swearing); OHro GEN. CoDe \$12842 (Page 1938) (perjury); PA. Stat. ANN. tit. 18, $\$ 4322$ (Purdon 1945) (false statement under oath).

117. E.g., Arcadia, Los Angeles, San Diego and South Gate, California; Akron and Springfield, Ohio; Rochester and St. Paul, Minnesota; Coral Gables, Florida; Evansville, Indiana; Louisville, Kentucky; and Seattle, Washington. 
register exceed the punishment for some of the most serious felonies. ${ }^{118}$ Although Pasadena, California, has such a provision, it limits its effect by providing that no person shall be convicted more than once on account of violations occurring by reason of failure to register on a series of days not interrupted by a conviction or acquittal under the ordinance. ${ }^{119}$

Almost all of the ordinances provide that the same penalty applies to any violation of the ordinance. This would include failure to register, failure to notify of change of address, failure to carry the registration card, ${ }^{120}$ or failure to furnish any information required by the ordinance, or furnishing false, untrue or misleading information.

\section{Access to the Registration Records and Files}

The majority of the ordinances contain some provision which limits access to the registration records to certain specified persons or organizations. Some provide that the registration records are confidential and make it unlawful to disclose to unauthorized persons any information contained in them. ${ }^{121}$ Some provide that the photographs may be exhibited to any person to help identify perpetrators of a crime, ${ }^{122}$ and some allow the free exchange of registration data with other police or law enforcement agencies. ${ }^{123}$

It is doubtful whether these provisions have any practical effect. Apparently, the general police practice is to treat these records in much the same manner as other police data. ${ }^{124}$ Therefore, the degree of disclosure of the materials varies from one police department to another. The practice of some police departments, especially in the smaller cities, of divulging such information to business firms could have a damaging effect on the rehabilitative efforts of an ex-convict who is seeking employment.

118. For example, a convicted person who enters Springfield, Ohio, and remains there for a year without registering would be liable for a possible fine of $\$ 181,500$ and over 181 years in prison.

119. Other localities employ a similar provision to limit the extent of the punishment for violations of their ordinances. E.g., Las Vegas and Reno, Nevada.

120. Only the Illinois drug addict registration statute provides different penalties for failure to register and failure to carry the registration card. "Any drug addict who fails to register as provided by this Act shall be imprisoned for not less than six months nor more than one year. Any drug addict who fails to carry his registration card as provided by this Act shall be fined not less than one dollar nor more than $\$ 100$ or impirsoned for more than one year, or both." ILI. ANN. STAT. c. 38, \$192.32 (Smith-Hurd Cum. Supp. 1953).

121. E.g., Cincinnati, Columbus and Iorain, Ohio; and Seattle, Washington (unlawful); Los Angeles and Pasadena, California; and Phoenix, Arizona (misdemeanor).

122. See, e.g., Los Angeles and Pasadena, California; Las Vegas and Reno, Nevada; Phoenix, Arizona; Jersey City, New Jersey; and Harrisburg, Pennsylvania.

123. See, e.g., Los Angeles and Pasadena, California; Las Vegas and Reno, Nevada; Phoenix, Arizona; and Harrisburg, Pennsylvania.

124. This is more likely to be true in a locality in which the ordinance provides only that the registration information shall become part of the permanent records of the police. E.g., Miami Beach and St. Petersburg, Florida. 


\section{The Criminal Registration Ordinances in Operation}

The registration process, the police enforcement of the ordinances, the prosecutions under the ordinances, and the minor judiciary's disposition of the violations charged were observed in studying the practical application of the criminal registration ordinances. The information upon which the following discussion is based was obtained, to a large degree, from interviews with officials and members of the Philadelphia and Camden, New Jersey, Police Departments ${ }^{125}$ and from their records. Additional information was obtained through correspondence with police officials of other localities.

\section{Sources of Information Available to Convicted Persons Regarding Existence of the Ordinances}

Substantial compliance with the ordinances can be obtained only if those persons who are required to register have been informed of their obligations. A large number of prisons advise their inmates, upon discharge, of the possible existence of these ordinances and suggest that they ask their local police whether or not such an ordinance is in effect. It is more likely that this policy would be followed by penal institutions situated near localities which have these ordinances. ${ }^{126}$ In addition, many parole and probation officials in cities which have ordinances advise the exconvicts reporting to them to register with the police department. ${ }^{127} \mathrm{~A}$ majority of the individuals, who were observed as they registered with the

125. Due to the.confidential nature of many of these sources in most cases it has been necessary to omit the names of the persons involved.

126. The warden of the Lehigh County Prison informs all discharged prisoners of the existence of the Allentown, Pennsylvania, ordinance. Letter from Sergeant Francis McCafferty, Allentown, Pennsylvania, Police Bureau of Identification (March 16, 1954). In a letter of March 23, 1954, Denver E. McWilliams, Supervisor of the Bureau of Identification and Records of the Phoenix, Arizona, Police Department states: "The State Board of Pardons and Paroles and the Arizona Prison authorities advise all releasees of this ordinance, and other officials, such as the sheriff's office, Adult Probation Office, judges, etc., have sent many convicted persons to this department to register." The South St. Paul, Minnesota, Police Department reported that it is advised by the state whenever a felon is released, and that the felon is also advised of his registration obligation by the releasing agency. Letter from Louis Fuller, Chief of Police of South St. Paul, Minnesota (March 26, 1954). The Cincinnati, Ohio, Police Department stated: "Probation and parole authorities and penal institutions notify all paroled or released prisoners of the provisions of the ordinance." Letter from Stanley R. Schrotel, Chief of Police of Cincinnati (July 26, 1954). A few of the individuals interviewed upon reporting to the Philadelphia police stated that they had been advised to register upon discharge from a penal institution.

The California Sex Criminal Registrtaion Act requires all penal officers to advise sex criminals, upon discharge, of the registration act, and to secure from such persons a signed statement to the effect that they have been so advised. Notification of such release must then be sent to the State Bureau of Identification. The Act also has a similar provision applicable to courts placing persons convicted of sex offenses on probation or discharging such persons upon payment of a fine. CaL. Penal Code $\$ 290$ (Supp. 1953).

127. Letter from O. L. Blough, Chief of Police, Harrisburg, Pennsylvania (March 29, 1954). See also letters from Phoenix, Arizona, and South St. Paul, Minnesota, police departments, supra note 126. 
Philadelphia police, stated that they had learned of the registration requirement from their parole or probation officers. Every parolee who has been released from a Pennsylvania penal institution should know that he may be required to register, since each is given a list of rules governing his parole, one of which provides:

"If, by the provision of any municipal, county, State, or Federal law, ordinance, or order, you are required to register as a person convicted of a crime, you will register with the proper authority immediately upon arrival in such locality." 128

Various Philadelphia probation authorities disclosed that they had been requested by the Philadelphia Police Department to send all persons on probation to the Identification Division to be registered. The members of the probation division did not have a copy of the Philadelphia ordinance, and their only knowledge of the ordinance seemed to be that generally it requires a person convicted of a serious offense to register. They stated that it was their practice to send everyone on probation to the Identification Division and allow the Division to decide whom it would require to register. However, a few members of the probation division did state that in certain cases they would not send a person on probation to register. For example, one probation officer said that he thought that a person who had been given a suspended sentence on a charge of assault and battery by automobile, should not be required to register under the ordinance; and, therefore, he would not necessarily send such a person to register. ${ }^{129}$ As a result of the attitude of the probation department, many persons not affected by the Philadelphia ordinance were sent to the police to register; while it seems that quite a few who were required to register were not advised of their obligation to do so, and possibly as a result thereof, they were placed in a position vulnerable to prosecution for failure to register.

A person may also learn of his registration obligation from judges, police and the "grapevine." Many Philadelphia judges advise persons who are given suspended sentences to "go upstairs and register," and a similar practice is probably carried on by judges in other jurisdictions. ${ }^{130}$ Often the police will advise an individual who has violated the ordinance to register, although they may not charge him with a violation. The police do this primarily with individuals who are being questioned about incidents

128. A Philadelphia registrant, upon being interviewed, stated that he would have disregarded his parole officer's instructions to register had he not noticed similar instructions on his parole papers. It appears that some parole officers, in Philadelphia, at least, fail to impress upon the parolee that failure to register is a criminal offense. One prisoner, who had failed to register after being advised to do so by his parole officer, stated that he thought he had "gotten away without registering" because his parole officer had not mentioned the matter after the initial interview.

129. Although it is possible that a person given a suspended sentence need not register, see text at note 64 and note 64 supra, the practice under the Philadelphia ordinance is to require such a person to register.

130. See letter from Phoenix, Arizona, Police Department (March 23, 1954) supra note 126. 
in which they are not directly involved. ${ }^{131}$ It appears that a significant number of registrants have learned of the existence of these ordinances through the "grapevine." A few persons who registered in Philadelphia indicated that they had learned of the ordinance through friends. The St. Paul, Minnesota, Police Department reported that a surprising number of individuals come directly to the police department upon entering the city, and state that they heard about the existence of the St. Paul ordinance while in some other city. ${ }^{132}$ Many police officials interviewed believed that the existence of these ordinances was common knowledge among persons with criminal experiences.

Although no ordinance was discovered which required the posting of notices as to the existence of the ordinance, the Lakewood, New Jersey, Police Department's policy is to distribute such notices to hotels, bus terminals, restaurants, the post office and various other business establishments. ${ }^{133}$ There has been widespread publicity only in St. Paul, Minnesota, where the public has been informed of the existence of the ordinance through many newspaper articles and speeches on radio, television, and to various social groups. ${ }^{134}$ Some of the other localities apparently rely on the publicity accompanying both the adoption of the ordinance and the first few arrests and convictions. ${ }^{135}$

It thus appears that persons within the scope of the ordinances probably know of their existence. This is especially true of those who have been convicted and placed in a penal institution or on probation or parole in a locality having a criminal registration ordinance. Unfortunately, a transient from an area in which these ordinances are not in effect might not be aware that they exist elsewhere. ${ }^{136}$ Therefore, he must rely almost entirely upon the "grapevine" or "prisonwise" friends. A provision in the ordinances, requiring the posting of notices in public places, ${ }^{137}$ would seem to be a desirable and necessary method of publicity.

131. See text following note 155 infra, with reference to the practice of not always charging persons discovered to be in violation of the ordinance.

132. Letter from N. C. McMahon, Chief of Police, St. Paul, Minnesota (March $22,1954)$.

133. Letter from W. L. Comstock, Chief of Police, Lakewood, New Jersey (Feb. 17, 1954).

134. Letter from N. C. McMahon, Chief of Police, St. Paul, Minnesota (March 22, 1954). The Cincinnati, Ohio, ordinance has been publicized through press and radio facilities. Letter from Stanley $R$. Schrotel, Chief of Police, Cincinnati, Ohio (July 26, 1954). The Jersey City, New Jersey, ordinance has been published in all local newspapers. Letter from James L. McNamara, Chief of Police, Jersey City, New Jersey (July 20, 1954).

135. Letter from Dan B. Hudson, Chief of Detectives, Evansville, Indiana (March 15, 1954); letter from Henry I. Fink, Acting Chief of Police, Santa Ana, California (August 5, 1954).

136. For example, an ex-convict from the northeast section of the country could not be expected to know that these ordinances exist in other areas when police officers in the northeast evidently do not know they exist. One official from a northeast locality requested that we define "criminal registration ordinance." Ietter from Captain John Graham, Bureau of Records, Police Department, Lowell, Massachusetts (March 28, 1954). See text following note 27 supra.

137. See text at note 133 supra. 


\section{Police Knowledge of the Ordinances and Their Provisions}

Proper administration and enforcement of a criminal registration ordinance can be accomplished only if the enforcement personnel have a thorough knowledge of its provisions. In Philadelphia, the personnel of the Identification Division, which handles the registration process, were very familiar with the ordinance's provisions, with one exception. Although Division personnel were informing the registrants of their obligations, they were misinforming them as to one requirement. ${ }^{138}$ The registration identification card, which is given to the registrant, contains a statement that the card must be carried at all times. ${ }^{130}$ All the Division personnel, as well as the sergeant in charge, believed that the ordinance contained such a provision. A quick check of the ordinance, copies of which were readily available in the Identification Division, would have shown that there is no provision for carrying or even issuing such a card. The sergeant in charge later stated that informing a registrant to carry the card at all times was "good advice and for the registrant's own convenience."

In contrast to the Identification Division's knowledge of the ordinance, the knowledge of the enforcement personnel was inadequate. Under the organization of the Philadelphia Police Department, the enforcement of the criminal registration ordinance will usually fall upon detectives, rather than uniformed patrolmen. ${ }^{140}$ For the most part, copies of the ordinance were not available to the individual detectives. However, a few detectives interviewed did have copies, and some of the detective divisions had copies in loose leaf ordinance and statute books which were available to any officer. It appeared that most detectives and uniformed policemen knew that some kind of registration law existed, but did not seem to know the specific content of the ordinance. A considerable majority of the detectives interviewed believed that failure to carry a registration card was a violation of the ordinance, and several persons were officially charged with such a violation. This mistake was caused partially by the statement on the back of the registration card, ${ }^{141}$ and partially by a false analogy of the registration card to Selective Service registration cards and drivers' licenses. With few exceptions, even those officers who understood that failure to carry a card was not a violation did not know what persons are required to register and they acted on the belief that anyone convicted of any crime

138. In first observing the registration process it was noticed that registrants were not being informed of their obligations under the ordinance. Upon being questioned about the importance of this, the police officials stated that they usually do inform the registrants and that the few instances observed were probably caused by their being too busy. Later observations confirmed this statement.

139. See text at note 93 supra.

140. For any offense more serious than drunkenness and disorderly conduct, the detectives determine the particular offense to be charged against an individual. It is usually beyond the scope of a uniformed policeman's duties to determine whether or not a person has violated the registration ordinance.

141. See text at note 93 supra. 
at any time is under the registration liability. ${ }^{142}$ However, efficient use is made of the officers' knowledge that registered criminals do carry registration cards. ${ }^{143}$

\section{Police Attitude Toward the Ordinances}

The attitude of enforcement officials toward the Philadelphia ordinance was divided. All personnel in the Identification Division were in favor of the ordinance. The sergeant in charge believed that, as the registration information increased, the detective divisions' task of protecting society from criminals would become easier. The same opinion was expressed by the Camden, New Jersey, officials. On the other hand, the vast majority of the Philadelphia detectives were apathetic to the ordinance. Although many believed that the ordinance was desirable and favored its registration aspects, they thought it was ineffective. Among the reasons they gave for the inutility of the ordinance were: (1) the charges of violation are always thrown out by the magistrate $;^{144}(2)$ only indigent defendants ever serve time on a violation of the ordinance because it is not constitutional and will never be sustained against a defendant who has a lawyer; ${ }^{14 \overline{5}}$ (3) detectives are too busy to check an individual's record for the information necessary to sustain the charges; (4) the fact that an individual is usually arrested with other charges against him eliminates the need to hold him on the violation of the ordinance; ${ }^{146}$ and (5) the police cannot arrest a person solely because he is violating the ordinance since there is no way of detecting the violation. ${ }^{147}$

A surprisingly large number of police officials expressed opposition to the ordinance and believed that it was unconstitutional. Some based their belief on the thought that the ordinances were indistinguishable from the unconstitutional New Jersey "gangster" law ; ${ }^{148}$ while others merely said that this was not the kind of control that the police should have. A few stated that once a man "serves his debt to society" he should be free and not constantly harassed by the police.

However, some detectives stated that they were in favor of the ordinance and did make use of it. One detective expressed favor because he thought that the ordinance kept criminals out of town, ${ }^{149}$ created the impression among registered criminals that they were under constant police

142. After this study had begun and several interviews had been held with police, additional copies of the ordinance became available to the enforcement personnel, and the later phases of the study showed that police knowledge of the ordinance's provisions had increased.

143. See text at note 97 and note 97 sipra.

144. Compare text following note 183 et seq. infra.

145. See text following note 176 infra.

146. See text following note 159 and Appendix $E$ infra.

147. See text following note 95 supra.

148. See text at notes 11,12 and notes 11,12 supra.

149. The detective had first-hand knowledge of a few cases in which undesirables stayed out of Philadelphia because of the ordinance. 
surveillance, and informed local police of a transient criminal's entry into the city. Other detectives were in favor of the ordinance because they could use it occasionally and selectively "to make it rough on a fellow" they know is "wrong," or to hold a man until they can check the details regarding a more serious crime. . $^{150}$

\section{The Registration Process}

In Philadelphia and Camden, New Jersey, any person required to register may do so at any time, as the police division which administers registration is open twenty-four hours a day. Although he is not in police custody, the registrant is usually accorded the same treatment as persons arrested and "booked" for a hearing. However, the identification process of any arrested person is at all times given prior attention, and the registrant must wait until that is completed. This priority arises because a police officer is waiting for the prisoner, and not necessarily out of disregard of registrants. The registration process takes from fifteen minutes to one hour in Philadelphia and about ten minutes in Camden, New Jersey, although in Camden the registrant must then wait until his photograph is developed.

In Philadelphia when a criminal appears for registration the police clerk at the Identification Division fills out three forms. The first form is a registrant's general information sheet. The ordinance enumerates information which must be obtained about a registrant's criminal record, ${ }^{151}$ and the form follows this enumeration, omitting to ask, however, whether a criminal's sentence or sentences have been commuted and whether he has been paroled. Under the ordinance the superintendent of police may also request any other relevant information, and the form requires from the registrant information concerning the length of time he has been at his present address, his addresses during the past three years, intended address, expected length of stay in the city, nationality, place of birth, naturalization (including where and when), a physical description, ${ }^{152}$ any aliases, and present occupation. Also required is the name and location of penal institutions in which the criminal has served sentences. Usually it is impossible for the registrant to furnish all this information and the clerks do not insist that the forms be completely filled out. A clerk takes this form and checks the police records to determine if the person has a prior record on file. ${ }^{153}$ If the registrant has a police record, a photograph will be taken only if the one in the file is more than two years old. The

150. See text following note 166 infra.

151. The Philadelphia ordinance requires the registrant's number, time and place of convictions, nature of the crimes, sentences imposed, sentences, if any, which were commuted and any paroles granted.

152. The Philadelphia police are particularly alert for marks or scars which would indicate that the registrant is a drug addict.

153. At Camden no attempt is made to check the prior records until after the registrant leaves and his fingerprints are classified. 
second form is a fingerprint card. Fingerprints are nearly always taken, and the form is filled out in triplicate. The third form is the registration card which is given to the registrant. All three of these forms must be signed by the registrant. The general information sheet is filed under the registrant's identification number, and a notation is made on his police record that he has registered. One set of fingerprints is placed in the police files, one set is sent to the state police and another is sent to the Federal Bureau of Investigation. ${ }^{154}$ On the set sent to the FBI there will appear a notation that the person has registered under the ordinance. The FBI upon receipt of the fingerprint card will classify the prints and check its records for the individual's dossier. A notation of the date and place of criminal registration will be made on the master record, and a mechanically-reproduced copy of the individual's complete previous records, showing all events (including criminal registration) for which the FBI received a set of fingerprint cards, will be sent to every former police source from which the FBI received fingerprint cards. This record will contain a list of all past and present orders of various law enforcement agencies showing that a particular person was or is wanted by such agencies. As a result, regardless of the information secured from the registrant, the police will get a full and complete report on the registrant's prior record and present status.

\section{Enforcement of the Ordinances}

Enforcement of the ordinances is accomplished both by informing a convicted person of his registration obligation ${ }^{155}$ and by prosecuting when violations occur. Although a person may be arrested solely because detectives know he is violating the ordinance, no such case was found in Philadelphia or Camden. However, some persons were arrested who were suspected of being involved in a crime and later found to be in violation of the ordinance. An arrested person, the arresting officer, and any complainants go to the detective division for interrogation which will determine the offense or offenses to be charged. A great many violations of the criminal registration ordinance become apparent at this time, either through the voluntary admission of the person that he was convicted of a crime and has not registered, or through a check of the police record and the criminal registration files. Most of the charges of violation made in Philadelphia during the course of this study resulted from the information thus secured. Usually the detectives are instructed to lodge every offense for which the person may be convicted, but not everyone found to be in violation of the criminal registration ordinance is so charged. In

154. The Las Vegas, Nevada, workers' registration ordinance specifically provides for a set of fingerprints to be sent to the FBI. Most of the criminal registration ordinances allow such information to be sent to any law enforcement agency. See text at note 123 supra. Although the Philadelphia and Camden ordinances are silent in this respect, the practice always is to send a copy of fingerprints to the FBI.

155. See text following 125 supra. 
addition, a number of cases were found in which an individual had been previously arrested in Philadelphia for an offense and, at the same time, he had been in violation of the ordinance but the latter offense had not been charged. A possible explanation for this is that the available personnel in a particular criminal investigation division temporarily could not complete all their administrative tasks. Under such circumstances it is only natural that a detective will not thoroughly examine the minor cases and, having a substantial basis for a more serious charge, he will have neither the time nor the inclination to check the details necessary to charge a violation of the criminal registration ordinance. Under such circumstances a detective might forget to list a violation even though he has the relevant information. Occasionally, a violation is discovered only after the person has been taken to the Identification Division and fingerprinted and a report received from the FBI.

An examination of police records and of reports from other localities indicated that the Philadelphia police were not alone in failing to lodge a charge against arrested persons who were in violation of the ordinance. ${ }^{156}$ A pattern of selective enforcement was demonstrated, but whether such a pattern was intentional or not was difficult to determine. ${ }^{157}$

\section{Prosecutions Under the Ordinances}

It is difficult to determine what violation of the ordinance is being charged either from an examination of the scanty records or from interviews with the officials who lodged the charges. Generally, in Philadelphia, the charge stated in the records is merely "violation of the criminal registration ordinance." Occasionally, the notation is "failing to carry a criminal registration card" or "failing to register." Within the past few years, it is probable that no one has been charged with a technical violation of the ordinance, such as failure to notify the police of change of address, ${ }^{158}$ or supplying false information. 150

During the first nine months of 1953 there were 68 persons charged with violating the ordinance, including one person who was charged with a violation on two different occasions. Of these 69 cases only 19 involved

156. See Appendix D infra (San Jose, California and St. Paul, Minnesota). The police records indicated that many persons previously had been arrested in various localities which have ordinances but that they were not charged with violating the ordinances although their records at the time of arrest showed that they were in violation.

157. Because of the more intensive study in Philadelphia, this pattern was more closely discerned and will be discussed below. The information obtained from other localities demonstrates that the enforcement of these ordinances varies from locality to locality. See Appendices C and D infra.

158. One reported Los Angeles, California, case resulted from the failure of a registrant to notify the police of his change of address. In re Guy Digiuro, 100 Cal. App.2d 260, 223 P.2d 263, rehearing denied, 100 Cal. App.2d 260, 223 P.2d 873 (1950). See text at note 185 infra.

159. No official was found in Philadelphia who could recall that either he or any other official had ever charged anyone for any offense under the ordinance other than either failure to register or failure to carry a registration card. 
persons who were charged solely with violating the ordinance; in the other 50 the individuals also had other charges lodged against them. ${ }^{160}$ These 50 cases were disposed of as follows: in 12 the persons were discharged on both the criminal registration violation charge and the other charge; in 19 the persons were discharged on the criminal registration violation charge but held for court on at least one of the other charges lodged against them; in 1 the person was turned over to military authorities; in 4 the individuals were fined for disorderly conduct and then discharged; and in 14 the persons were fined on the criminal registration ordinance violation. ${ }^{161}$ In 7 of the 19 cases in which the only charge lodged was violation of the criminal registration ordinance, the persons were found guilty and fined, while in the other 12 the individuals were discharged. The total number of cases in which the persons were subjected to the penalties of the ordinance was $21 .{ }^{162}$

Persons Charged with Violating the Philadelphia ${ }^{163}$ Ordinance Who Appeared Not to $B e$ in Violation: In 24 of the 69 cases there appeared to be no basis for the charge of violation. ${ }^{164}$ In 11 of these 24 cases the individuals were registered at the time the charge was lodged against them. They may have been in technical violation, but this was not indicated in the record, nor brought out in interviews with the officials involved; most of these persons were charged with "failure to carry a registration card" which is not a violation of the ordinance. In the other 13 cases the persons did not have such prior records which would have necessitated their registering. Many of these individuals had long criminal records, but not such as to require registration in Philadelphia. ${ }^{105}$ In some of these cases, because of a large number of arrests, the records gave the impression that an individual had a long history of criminal activity, but careful examination disclosed that there had been no convictions. In each of these 24 cases, the fact that the individuals involved had not violated the ordinance would have been obvious to the officers making the charges if they had known the details of the ordinance ${ }^{168}$ or made necessary inquiries.

160. See Appendix $\mathrm{E}$ infra.

161. In 6 of these 14 cases, the individuals were discharged on the other charges, but in the other 8 the persons involved were also held for court on the other charges.

162. See text at notes 182,183 and notes 182,183 infra.

163. Unfortunately, information concerning this aspect of the enforcement and prosecution under the ordinances could not be obtained from other localities.

164. The police files indicated that in the other 45 cases the persons were not registered and had a prior record which would have required them to register.

165. In one case the individual had a record of ten arrests dating back to 1937 with convictions of larceny, holdup, and conspiring to violate the internal revenue laws. But a close examination of his record by one thoroughly acquainted with the Pennsylvania legislative pardon statute (see note 58 supra) and the Philadelphia ordinance would reveal that the defendant was released from jail prior to 1939 , in which case he received an automatic legislative pardon, and that the character of the offenses committed or the length or place in which the sentence was served was not such as to require registration.

166. See text following note 140 supra. 
Selective Prosecution as a Detention Technique: In Philadelphia some cases were found which indicated that the prosecutions were for the purpose of detaining the individuals for investigation. For example, in one case the police received information that a certain person was involved in a murder. The individual's prior record disclosed that he had been arrested in the South on two previous occasions, once for investigation and once for patronizing a "bawdy house"; but on both occasions he had been discharged. The only other prior arrest in his record was for reckless driving and operating a motor vehicle while under the influence of alcohol. He paid a fine on the first charge and the second was dropped. There is little doubt that this person was being held by the police for investigation with respect to the murder charge, although it is possible that the officer who charged the violation acted on the advice of the Identification Division that the individual "had a record," without understanding the character of the record or realizing that anything more than a mere record is required in order to prosecute a person for violating the ordinance.

There is probably some correlation between the number of persons who have been charged solely with a violation of the ordinance and the use of the ordinance for detention purposes. In some localities police departments admit openly that to them temporary detention is the most significant use of their ordinance, ${ }^{\mathbf{1 6 7}}$ although no information was submitted as to the number of persons so detained. ${ }^{168}$ The Philadelphia practice in this respect is not as clear as that of these other localities. The charge of violating the ordinance was the sole charge in only 19 of 69 cases. Of the 13 cases in which persons charged with violations did not have criminal records which required registration, only 6 involved individuals who were charged with some other offense, and in only 3 of these cases was the other charge sufficiently supported by evidence to warrant holding the individuals for court. It is possible that in all but the last 3 cases the charge of violating the criminal registration ordinance was used to detain the individuals.

Selective Prosecution as a Harassing Technique: The criminal registration ordinances can easily be adapted as an instrument for harassing undesirables. By following a program of general non-enforcement, some localities might be able to lull convicted persons into believing that the ordinance is a "dead letter." As a result, few persons would go through the registration process. Thus, the police could secure a rather powerful

167. See text at note 19 supra. The Rochester, Minnesota, Police Department reported: "This ordinance is of great value in investigation, as a person can be charged having a prior felony record, enabling us to hold until investigation is completed." Letter from $H$. M. Fitzpatrick, Captain of Detectives, Rochester, Minnesota (March 22, 1954). According to the District Attorney of Santa Clara, California, the City of San Jose did not charge anyone with a violation during 1952, although ". . . a few have been 'detained' under the ordinance while being investigated for more serious offenses." Letter from N. J. Menard, District Attorney of Santa Clara County (Nov. 4, 1953).

168. See "Disposition and Remarks" column in Appendix D infra, with respect to Las Vegas, Nevada, and San Jose, California. 
weapon to use selectively at their discretion against any person coming within the purview of the ordinance who might meet with their displeasure. ${ }^{169}$ For example, during the first eleven months of 1953, Louisville, Kentucky, prosecuted only two persons for violating its ordinance. ${ }^{170}$ Both individuals were asked to register and to leave town within 12 hours. The Louisville police report that only approximately 25 persons registered during the same period. ${ }^{\mathbf{1 7 1}}$ The report received from the Miami Beach, Florida, Police Department appears to demonstrate a policy of selective prosecution. During 1953 only about 80 persons registered under the Miami Beach ordinance, despite the transient character of the population. During the same period only 36 persons were charged with violating the ordinance. ${ }^{172}$ It is probable, considering the existence of a workers' registration ordinance in Miami Beach, ${ }^{173}$ that the existence of a substantial number of violators was brought to the attention of the Miami Beach police. Persons thus discovered to be in violation of the criminal registration ordinance were apparently neither charged with violation nor advised of their registration obligation. ${ }^{174}$ As a result, some 36 persons whom the police had some motive in detaining were charged with violation of the ordinance. Out of these 36,12 were fined, 13 were given jail sentences of from 5 to 60 days which were suspended "on good behavior" or "on condition subject leave town," and 10 were discharged. 175

A pattern of intentional selective application was not discovered in Philadelphia, although that seems to be the tendency. There appeared to be a greater chance that an individual in violation of the ordinance whom the police desired to detain, incarcerate or harass would be charged with a violation than an individual who, although in violation, was not presently obnoxious to the investigating official. This result is also confirmed by the attitude enunciated by many officers that they see no reason to charge an "otherwise law-abiding" individual with a violation. Some of the cases found in Philadelphia which reflected selective prosecution were as follows. A uniformed police officer lodged a charge of violating the ordinance against an individual who had come to the police station

169. Attention is called to the relatively low number of registrations and prosecutions in the following localities: Canton, Ohio; Harrisburg, Pennsylvania; Louisville, Kentucky; Rochester, Minnesota; and Santa Ana, California. See Appendices $\mathrm{C}$ and $\mathrm{D}$ infra.

170. See Appendix D infra.

171. See Appendix C infra.

172. See Appendices C and D infra.

173. See text at note 23 and note 23 supra.

174. However, a letter from $L_{t}$. Bruce Simmons, Supervisor of the Miami Beach Identification Bureau (Dec. 23, 1953), indicates that they do either prosecute or notify persons whose violation has been discovered from the workers' registration ordinance. It. Simmons stated that there were over 26,000 civilians registered during 1953 and usually $4 \%$ of civilian registrants have been convicted of a felony. However, only a felony conviction within ten years of entrance into the city raises criminal registration liability, and the high number of civilian registrations is misleading in that every worker must re-register each year.

175. The disposition of one charge was not given. 
inquiring about a girl who had been arrested as a narcotic user. Suspecting that this individual was also a "user," the officer questioned him concerning his prior criminal record. The individual stated that he had a criminal record but was not registered, and, therefore, a charge was lodged against him. ${ }^{176}$ In one case a tramp was charged with violation of the ordinance after he had been brought to the station house by a uniformed police officer for "answering back" when told "to move on." The detective stated that he charged the tramp with violating the ordinance after he had admitted during questioning that he had been convicted of burglary in New Orleans but had not registered. The charge was lodged because the detective wanted to "make it rough on the guy" even though he would be discharged in the morning. In another case the individual was apprehended in a tavern after having boasted to others that he was a well-known henchman of Willie Sutton, then currently the object of a police dragnet. According to the investigating detective, the individual was arrogant, obnoxious, and a self-admitted "cop-hater," which was "enough reason to get this guy on something." The most obvious case of selective prosecution involved the arrest of two known professional thieves. Both of these individuals had prior records of at least eleven arrests involving either larcency, robbery, or burglary in as many jurisdictions. Upon information that these individuals were responsible for a recent epidemic of pickpocketing at the baseball stadium the police arrested them while peacefully occupying their hotel room. The investigators, unable to sustain the pickpocket charge, charged the suspects with being professional thieves, and with violating the criminal registration ordinance. Both charges were dismissed when the magistrate sustained the argument of the suspects' attorney that the invasion of the hotel room to make an arrest without a warrant was a gross violation of the suspects' civil rights.

On the other hand, many detectives state that they lodge charges of violation of the ordinance regardless of their feeling toward the particular individual or their attitude toward the ordinance. They believe that it is their duty to charge all persons who may be guilty and to allow the magistrate, in the proper case, to suspend sentence or discharge the individual. Thus, in a case involving a robbery charge against a person who had previously been convicted of statutory rape, a Philadelphia detective also lodged a charge of violating the criminal registration ordinance, even though, because of his belief that the person was innocent of the robbery charge, the detective had spent five hours trying to break down the complainant's identification upon which that charge was based. One sergeant, who was in favor of the ordinance, stated that he found it particularly valuable in the case of drug addicts since such individuals are dangerous and it is the duty of a police officer to use any available technique to keep them off the streets.

176. But strangely enough, an answer that the person is not a criminal will not result in any further investigation to determine the validity of the answer. 
Prosecution Based on Information Obtained from Workers' Registration Ordinance: Some localities have both a criminal registration ordinance and a "workers' registration ordinance." 177 Since most employers in these localities will not hire anyone without a workers' registration card, most persons will be forced to register under the workers' registration ordinance in order to obtain employment. After a person has registered under this ordinance, his fingerprints are taken and a copy is sent to the FBI which returns any record that it might have on this individual to the local police. The police use this information to determine whether the individual had a prior criminal record which would require him to register under its criminal registration ordinance. If the individual is under the liability to register, the criminal registration file will indicate whether he has violated the ordinance by having failed to register. The Assistant City Attorney of Las Vegas, Nevada, reported that he knew of no case during the last two and one-half years in which anyone had been charged with violating the criminal registration ordinance as a result of information obtained from its workers' registration ordinance; ${ }^{178}$ but the Miami Beach, Florida, police stated that information for approximately $65 \%$ of the charges of violating its criminal registration ordinance was obtained from the workers' registration data. ${ }^{179}$ Atlantic City, New Jersey, which recently enacted a "transient workers'" registration ordinance, appears to follow a policy similar to that of Miami Beach. ${ }^{180}$

\section{Judicial Treatment of Cases Arising Under the Ordinances}

\section{Disposition of the Violation Charges by Philadelphia ${ }^{181}$ Magistrates}

Of the 69 cases in which charges of violating the criminal registration ordinance were lodged, in 48 the individuals were discharged and in 21 they were convicted and fined. In 17 of these 21 cases it appears that

177. E.g., Atlantic City, New Jersey; Miami Beach, Florida; and Las Vegas, Nevada.

178. Letter from Ralston O. Hawkins, Assistant City Attorney, Las Vegas, Nevada (Dec. 8, 1953).

179. Letter from It. Bruce Simmons, Supervisor of the Identification Bueau, Miami Beach, Florida (Dec. 23, 1953).

180. A recent newspaper article stated: "A city ordinance requiring the registration of all transient workers in this resort city [Atlantic City, New Jersey] has led thus far to the arrest of 21 undesirables, acting Detective Capt. James $H$. Farley, announced today.

"The ordinance, in operation since June 16 [1953] was enacted to impede the activities of hoodlums, drifters, and drug addicts. It has led to the fingerprinting and photographing of more than 5,000 migratory employees.

"The effectiveness of the measure is strengthened by a criminal registration ordinance . . . and by a state law making it mandatory for any person convicted of a narcotics offense to report to local authorities.

"...

"The Drive netted two men who were still on 'wanted' lists." Philadephia Inquirer, Aug. 2, 1953, \$ B, p. 3, col. 4.

181. The available information on the disposition of violation charges by the lower judiciary in other localities is given in Appendix $D$ infra. 
the persons involved were in actual violation. ${ }^{182}$ The individuals in the other 4 cases in this group did not appear to be in violation, because in 2 cases the prior record was not such as to require registration, and in the other 2 cases the individuals apparently had registered. ${ }^{183}$

Of the 48 cases in which the individuals were discharged, in 20 the persons involved did not appear to be in violation while in 28 , they did. ${ }^{184}$ Of the 20 cases in which the persons did not appear to be in violation, 9 involved persons who had previously registered, while in 11 the individuals did not seem to have a prior record which would have required them to register.

These figures indicate that the chance of being improperly convicted is slight in comparison to the chance of being discharged even though in violation. Only $19 \%$ (4 out of 21 ) of the convictions appeared to be improper. But $58.3 \%$ (28 out of 48 ) of those discharged appeared to be in violation. These figures also tend to substantiate the claim of many detectives that the magistrates usually dismiss the charges.

\section{Litigation of the Ordinances Above the Magisterial Level}

Apparently, there has been little litigation of the criminal registration ordinances above the level of the magistrates' courts. Three cases were found in which convictions under the Los Angeles, California, ordinance were declared invalid. In one case ${ }^{185}$ a conviction for failure to reregister under the Los Angeles ordinance following a change of residence was held invalid because the complaint failed to allege a prior conviction. In another case ${ }^{186}$ the conviction was invalidated because the prosecution had not presented evidence that any of the prior offenses which were committed in Oklahoma "would have been punishable as a felony" if committed in California. In the third case ${ }^{\mathbf{1 8 7}}$ the conviction was reversed on the ground that the evidence was insufficient to prove that the defendant resided in the city or remained there for twenty-four hours. This opinion is of particular interest since the court criticized the ordinance for its lack of clarity, particularly in its definition of "convicted person."

182. In 6 of these 17 cases the individuals were also held on other charges, in 4 they were discharged on the other charges, and in 7 no other charges were made.

183. In each of these 4 cases other charges were lodged but in only 2 were the individuals also held on the other charges.

184. In 12 of these 28 cases the individuals were held on other charges, in 14 the persons were discharged on all charges, in 1 the individual was fined on a charge of disorderly conduct, and in 1 the individual was turned over to military authorities.

185. In re Guy Diguiro, 100 Cal. App.2d 260, 223 P.2d 263, rehearing denied, 100 Cal. App.2d 260, 223 P.2d 873 (1950).

186. People v. James A. Pitt, Crim. Appeals No. 2777, Sept. 20, 1951. Since the prior criminal record of the defendant indicated that he had been convicted of such offenses, this reversal probably resulted because of the laxity of the prosecution.

187. People v. William J. Shirley, Crim. Appeals No. 1605, Los Angeles County Sup. Ct., Dec. 21, 1939. 
Communications from other localities indicate that some litigation, in addition to the three cases discussed above, has taken place. Although habeas corpus proceedings were commenced in 1949 in order to contest the Reno, Nevada, ordinance, the action was dropped at the request of the defendant after the trial court had denied the petition. ${ }^{188}$ The West Palm Beach, Florida, ordinance was declared invalid a number of years ago by the municipal court, but it was impossible to obtain further information concerning this case. ${ }^{189}$

The primary reason for the lack of litigation in this area probably is that many of the individuals who are convicted under the ordinances cannot afford legal representation. ${ }^{190}$ In addition, an appeal would not be prosecuted in most cases, since the penalties imposed by the courts are very light.

\section{Evaluation}

An evaluation of the criminal registration ordinances must consider both their social desirability and constitutionality, and since these two factors are interrelated, they will be discussed together. The social desirability of these laws will be determined by considering their objectives, the possibility of achieving those objectives, the possible restrictions upon the liberties of the persons affected, and the abuses to which these laws may and do lend themselves. These same factors are also relevant to the constitutional questions. Of course, these laws may be constitutionally valid, but undesirable in terms of social policy. Since the constitutionality of any particular ordinance depends upon its specific provisions, as litigated within the context of a specific factual situation, only the general constitutional grounds for attacking these laws will be dealt with here. ${ }^{101}$

The stated objective of the criminal registration laws is to aid the police in preventing criminal activities and apprehending the perpetrators thereof. ${ }^{192}$ The social desirability of such an objective cannot be criticized, and compulsory registration of criminally dangerous persons would appear to fall within the police power of the states. ${ }^{193}$ The Supreme Court of

188. Letter from Martin J. Scanlan, attorney for the defendant (Dec. 7, 1953).

189. Letter from C. Robert Burns, City Attorney, West Palm Beach, Florida (Nov. 10, 1953).

190. In Philadelphia a majority of the persons who were convicted of violating the ordinance and were not being held for court on another charge were committed to jail upon failure to pay the $\$ 100$ fine. In Phoenix, Arizona, a large number of persons were sent to prison for failure to pay relatively small fines. See Appendix D infra.

191. For a study of the constitutionality of the Philadelphia criminal registration ordinance, see Note, 11 TEMP. L.Q. 551 (1937). Though not discussed here, it must be remembered that individual ordinances are subject to attack under the various state constitutions, as well as the Federal Constitution.

192. See text following note 3 and text at note 20 et seq. supra.

193. Bryant v. Zimmerman, 278 U.S. 63 (1928) (upholding legislation which was directed toward unmasking the $\mathrm{Ku}$ Klux Klan by requiring the identification of membership by certain organizations having an oath as a prerequisite or condition of membership). See Cantwell v. Connecticut, 310 U.S. 296, 306 (1940) ("Without 
the United States has upheld some statutes which have imposed a registration and identification requirement upon persons who were thought to present a particular danger to the community. ${ }^{194}$ The privileges and immunities, due process and equal protection clauses of the Fourteenth Amendment, however, limit the states' police power in that the protection of society by state action must not unduly infringe upon individual liberties.

Limitations upon an individual's freedom of locomotion have been subjected to the test of the privileges and immunities and the due process clauses of the Fourteenth Amendment. ${ }^{105}$ Although the criminal regis-

doubt a State may protect its citizens from fraudulent solicitation by requiring a stranger in the community, before permitting him publicly to solicit funds for any purpose, to establish his identity and his authority to act for the cause which he purports to represent.").

194. See note 193 supra. Compare also City of Manchester v. Leiby, 117 F.2d 661 (1st Cir.), cert. denied, 313 U.S. 562 (1941) (upholding a city ordinance which required the registration and identification of persons who work as bootblacks or sell magazines, pamphlets and newspapers in the streets); United States v. Harriss, 347 U.S. 612 (1954) (upholding the constitutionality, inter alia, of statutory provisions for the registration of lobbyists); United States v. Peace Information Center, 97 F. Supp. 255 (D.D.C. 1951) (upholding the constitutionality of the Foreign Agent's Registration Act, 52 STAT. 631 (1939), as amended, 22 U.S.C. \$\$ 611-21 (Supp. 1950)). But cf. Hines v. Davidowitz, 312 U.S. 52, 71 n.3 (1941) (see text at note 100, supra). See Allutson v. Mallard, 106 F. Supp. 635 (E.D. Mich. 1952) (upholding Michigan statute requiring Communists to register with the State police).

195. Crandall v. Nevada, 6 Wall. 35 (U.S. 1867) ; Williams v. Fears, 179 U.S. 270,274 (1900) (the Court, although holding that a state law taxing persons hiring laborers to work elsewhere did not abridge the privileges and immunities clause did state: "Undoubtedly the right of locomotion, the right to remove from one place to another according to inclination, is an attribute of personal liberty, and the right, ordinarily, of free transit from or through the territory of any State is a right secured by the Fourteenth Amendment and by other provisions of the Constitution."); Territory of Hawaii v. Anduha, 48 F.2d 171 (9th Cir. 1931). See Pinkerton v. Verberg, 78 Mich. 573, 584, 44 N.W. 579, 582 (1889) ; Commonwealth v. Doe, $109 \mathrm{~Pa}$. Super. 187, 190, 167 Atl. 241, 242 (1933); Ex parte Hudgins, 86 W. Va. 526, 529, 103 S.E. 327, 329 (1920) ; Bauer v. Acheson, 106 F. Supp., 445, 451 (D.D.C. 1952) ("Thus, freedom to travel abroad, like other rights, is subject to reasonable regulation and control in the interest of the public welfare. However, the Constitution [Fifth Amendment] requires due process and equal protection of the laws in the exercise of that control."). See also Meyers, Federal Privileges and Immunities: Application to Ingress and Egress, 29 CORNELL L.Q. 489 (1944).

In Edwards v. California, 314 U.S. 160, 173 (1941), where a state statute making it a misdemeanor to bring or assist in bringing an indigent person into the state was declared invalid, four justices, in two concurring opinions, based their conclusion on the privileges and immunities clause. Justice Douglas' opinion, which was joined by Justices Black and Murphy, stated: "The conclusion that the right of free movement is a right of national citizenship stands on firm historical ground . . a state statute which obstructs or in substance prevents the movement must fall. That result necessarily follows unless perchance a State can curtail the right of free movement of those who are poor or destitute. But to allow such an exception to be engrafted on the rights of national citizenship would be to contravene every conception of national unity. It would also introduce a caste system utterly incompatible with the spirit of our system of government. It would permit those who were stigmatized by a State as indigents, paupers, or vagabonds to be relegated to an inferior class of citizenship. It would prevent a citizen because he was poor from seeking new horizons in other States. It might thus withhold from large segments of our people that mobility which is basic to any guarantee of freedom of opportunity." Id. at 181. Justice Jackson's concurring opinion, though more limited, was of the same tenor. He stated: "The right of the citizen to migrate from state to state . . . shown by our precedents to be one of national citizenship, 
tration ordinances do not completely limit an individual's right of locomotion, they do impose a rather heavy burden upon the individuals subject to them. ${ }^{196}$ The burden is directly proportional to the freedom of locomotion which the individual must have in his everyday life. For example, a convicted person who either desires to travel for pleasure or is required to travel by his employer might well abandon his activity because of the burdens of the ordinances; for, regardless of the seriousness or temporal remoteness ${ }^{197}$ of the crime for which he was convicted, such an individual must take the time, trouble and expense to determine if each locality has an ordinance and if he falls within its terms, and then he must comply with the requirements of those ordinances which affect him. In addition, under most of the ordinances, every subsequent entry into, or change of address in, that locality would require a notification to the police. ${ }^{198}$ Since these ordinances infringe upon the right of locomotion, which is a national right protected by the privileges and immunities clause of the Fourteenth Amendment, it is necessary to determine whether a legislature has a sufficient basis under the due process clause to restrict this right.

Substantive due process requires that there be a relationship between the objective sought to be attained and the means employed to achieve that end. The standard that governs the relationship between means and end depends upon the character of the rights involved. ${ }^{109}$ Restriction on the "indispensable democratic freedoms secured by the First Amendment . . must have clear support in public danger, actual or impending" 200 whereas economic rights require that there be a "substantial relationship" between the means and end. ${ }^{201}$ The present case lies between

is not, however, an unlimited one . . such citizen is subject to some control by state governments . . . it is here that we meet the real crux of this case. Does 'indigent' as defined . . . constitute a basis for restricting the freedom of a citizen, as crime (i.e. a fugitive from justice) or contagion warrants its restriction? We should say now, and in no uncertain terms, that a man's mere property status, without more, cannot be used by a state to test, qualify, or limit his rights as a citizen of the United States." Id. at 184.

196. See text following notes 81 and 150 supra.

197. See text at note 37 et seq. and text at and following note 69 supra.

198. See text following note 89 supra.

199. In Thomas v. Collins, 323 U.S. 516 (1945), the Court stated: ". . . it is the character of the right, not of the limitation, which determines what standard governs the choice." Id. at 530 .

The means adopted to obtain the end do not, however, have to be the best available. In Jacobson v. Massachusetts, 197 U.S. 11 (1905), the Court stated: "It is no part of the function of a court or a jury to determine which one of two modes was likely to be the most effective for the protection of the public. . . . [T] hat was for the legislative department to determine in the light of all the information it had or could obtain." Id. at 30 .

200. Thomas v. Collins, 323 U.S. 516, 530 (1945). The Court also stated that where First Amendment rights are involved: "The rational connection between the remedy provided and the evil to be curbed, which in other contexts might support legislation against attack on due process grounds, will not suffice. These rights rest on firmer foundation." Ibid.

201. E.g., Cities Service Gas Co. v. Peerless Oil \& Gas Co., 340 U.S. 179 (1950). In this case the Court stated: "Like any other legislation, a price-fixing 
these two extremes. The liberty protected by the due process clause of the Fourteenth Amendment has not been interpreted as including all of the rights protected by the first eight amendments of the Constitution, ${ }^{202}$ nor has the scope of the meaning of "liberty" been precisely defined, but it surely includes more than exemption from physical restraint. The First Amendment rights have all been read into the concept of liberty in the Fourteenth Amendment because of their importance to the very existence of a democratic system of government. How far the concept of liberty under the Fourteenth Amendment will extend is uncertain. The philosophy of any democratic system would seem to require, in addition to the First Amendment rights, that the integrity of the person be protected; that each individual be free from a constant atmosphere of police surveillance; that each individual be free from legislation which is an inherent vehicle for potential abuse; and that the freedom of locomotion, discussed above, be preserved. In short, the liberty involved here is that which distinguishes a democracy from the state police system of a dictatorial regime. ${ }^{203} \mathrm{Be}-$ cause these rights are so important in maintaining a democratic system, they should be included within the concept of liberty in the Fourteenth Amendment, and the standard for scrutinizing the relationship between means and end should be closer to that involved in the First Amendment cases rather than that involved in the economic regulation cases.

The relationship between means and end will depend upon whether registration and identification of convicted persons enables the community to protect itself from a genuine evil or danger; and this in turn will depend upon whether these persons actually present such an evil or danger, and whether the persons charged with enforcing these laws deliberately fail to enforce them so that they may be utilized for purposes other than the stated objective, or, if they are enforced and the persons have registered, whether the information thus obtained is available to and used by the police. The most difficult and also the most significant factor in determining the social desirability and constitutionality of these laws is whether convicted persons present a sufficient danger to the community to warrant the imposition of the registration requirements. In the registration laws upheld by the Supreme Court, the registration liability was imposed on individuals who were presently engaged in activity that could be considered dangerous. ${ }^{204}$ The criminal registration laws, on the other

order is lawful if substantially related to a legitimate end sought to be attained. Nebbia 2. New York, 291 U.S. 502 (1934) and cases therein cited." Id. at 186. Dicta in cases subsequent to Nebbia $v$. New York had indicated that the standard of relationship between means and end in economic cases was that there be only a "rational basis." See West Virginia State Board of Education v. Barnette, 319 U.S. 624, 639 (1943). See also Thomas v. Collins, 323 U.S. 516, 527 (1945).

202. See, e.g., Adamson v. California, 332 U.S. 46 (1947).

203. See Kempner, supra note 22 , for a discussion of the thoroughness of the Nazi regime in its control of the German people.

204. Bryant v. Zimmerman, 278 U.S. 63 (1928) (identification of membership at time of enactment and periodically thereafter). See Cantwell v. Connecticut, 210 U.S. 296, 306 (1940) (registration required prior to solicitation of funds). 
hand, do not require registration because the individuals are presently engaged in dangerous activity, but because they have engaged in anti-social behavior in the past. The theory of the criminal registration laws, therefore, must of necessity rest upon the assumption that persons who have once been convicted of a crime are sufficiently dangerous to warrant the imposition of the registration burden for the protection of the community. Any evaluation of the criminal registration laws is dependent upon the validity of this assumption. The available statistical information concerning recidivism is not very useful in evaluating the quantitative probability that an individual with a particular pattern of prior criminalty is more likely to engage in anti-social behavior than individuals without such a prior history. ${ }^{205}$ Although criminologists and sociologists have studied the problem of recidivism and have come forth with conflicting views as to the likelihood that convicted persons will recidivate, ${ }^{206}$ none have been able to state with any degree of assurance that the one factor, i.e., having previously been convicted of a single crime, is a sufficient criteria for predicting future criminality. ${ }^{207}$ The research in the area of parole and probation relapse prediction has aptly demonstrated that many factors are

See also, United States v. Peace Information Center, 97 F. Supp. 255 (D.D.C. 1951) (persons engaged in dispensing foreign propaganda at time report required); United States v. Harriss, 74 Sup. Ct. 808 (1954) (persons engaged in lobbying at time report required).

205. For a comprehensive survey of the studies that had been made up to 1932 on the problem of recidivism see MichaEl and ADLER, AN INsTitute of Criminologx ANd of Criminal Justice, 123-77 (1932) (Report of a Survey Conducted for the Bureau of Social Hygiene under the Auspices of the School of Law of Columbia University).

The Federal Bureau of Investigation's Uniform Crime Reports are of some value in that they do report the number of persons who have been arrested for particular offenses during a particular year who had, at the time of such arrest, prior arrest fingerprint records on file with the FBI. Unfortunately this statistical material is based upon arrests rather than convictions and thus can be somewhat deceptive. The mere fact that an individual has a prior arrest or conviction will make it more likely that he will be arrested in the future, but there may not be sufficient evidence to warrant a conviction or, in many cases, even a holding over on preliminary examination. See Hopkins, Our Lawless Police 88 et seq. (1931). See also text at note 213 and note 213 infra.

206. See note 205 supra.

207. In fact, the conclusions drawn by MrCHAEI AND ADLER, op. cit. supra note 205 , after reviewing the various studies in recidivism were as follows: "Our critical appraisal of the researches reported in the preceding section can be succinctly summarized in the following statement: These researches do not afford a single definite and clearly valid answer to any of the foregoing questions. We do not know whether criminals can or cannot be differentiated from non-criminals in terms of any set of factors. We do not know whether classes of individuals whose offenses are different in terms of the criminal law can be differentiated from one another. We are similarly ignorant with respect to each of the other questions. Unless it is unfair to say that it was the purpose of the researches summarized to answer questions of this sort, it cannot be thought an unjust evaluation of them to say that they have failed utterly to accomplish the purpose for which they were undertaken. All of the investigations which have been conducted not only have not advanced our knowledge of the causes of criminal behavior, but what is worse, they have not yielded conclusions relevant to the only specific problems by which they can conceivably have been directed. The knowledge which has been accumulated by so much industry and effort not only lacks etiological significance but is inconclusive in its own terms." Id. at 178. 
relevant. $^{208}$ Unlike the habitual criminal laws which require a fait accompli before the habitual criminal penalty is imposed, the vast majority of the criminal registration ordinances require merely one conviction and impose the registration burden without any indication of future criminal tendency. ${ }^{200}$ In view of the lack of any definite knowledge as to whether the mere fact that persons who have once been convicted of a crime are significantly more dangerous to the public safety than the general population, it is questionable whether there is a sufficient relationship between the registration requirement and the objective of these laws under the standard set forth above.

Although analysis of available statistics ${ }^{210}$ may lead to the conclusion that a person with a particular pattern of criminality is more likely to become involved in future criminal activity than a person without such a prior record, the failure to discriminate more sharply in the types of crime included within the scope of the ordinances ${ }^{211}$ and the time within which the criminality must have occurred ${ }^{212}$ also tends to show a lack of substantial relationship between means and end. There is some relationship between the character of a prior criminal act and the likelihood of recidivism, ${ }^{213}$ but the indiscriminate inclusion of "any crime," 214 "any

208. See discussion of various studies in Allen, $A$ Reveize of Parole Prediction Literature, 32 J. CrIm. L. \& CrIMInology 548 (1942); Monachesi, American Studies in the Prediction of Recidivism, 41 J. CrIm. L. \& Criminology 268 (1951) ; Michael and Adler, AN Institute of Criminology and Criminal Justice 124 et seq. (1932). See also Glueck, Pre-Sentence Examination of Offenders to Aid in Choosing a Method of Treatment, 41 J. Crm. L. \& Crrminology 717 (1951).

209. None of the ordinances provide for a finding that any particular individual constitutes a danger to the community or that he demonstrates a tendency toward criminality. The failure to provide for such a finding may raise a procedural due process question. In Skinner v. Oklahoma, 316 U.S. 535 (1942), Chief Justice Stone, in a concurring opinion, stated: "A law which condemns, without hearing, all the individuals of a class to so harsh a measure as the present [sterilization] because some or even many merit condemnation, is lacking in the first principles of due process." Id. at 545. Although criminal registration laws do not involve such a "harsh" measure as was present in the Skinner case, nevertheless, the same principle can be applied. Compare the procedural requirements upheld in Buck v. Bell, 274 U.S. 200, 206-07 (1927).

210. Sellin, The Criminal History of Released Prisoners, 35 J. CRIM. L. \& Crimrnologx 223 (1944). See generally the Uniform Crime Reports published by the Federal Bureau of Investigation; Zuckerman, Barron, \& Whittier, $A$ Follow$U p$ Study of Mimesota State Reformatory Inmates-A Preliminary Report, 43 J. Crmir. L. \& Crimrnology 622 (1952).

211. See text at note 37 et seq. supra.

212. See text at note 69 and text following note 73 supra. A study of 345 individuals released from the Minnesota State Reformatory during 1944 and 1945 revealed that of those releasees who recidivated during the seven year period following release, only $2.3 \%$ did so for the first time during the the last two years covered by the study. Zuckerman, Barron, \& Whittier, supra note 210 , at 626 .

213. Although the statistics available are of very little use for the purposes of this study, an analysis of the Federal Bureau of Investigation Uniform Crime Reports for the years 1938 to 1946 inclusive discloses that there is a significantly greater chance that a person arrested for narcotic offenses, vagrancy, drunkenness, forgery, counterfeiting, or robbery will have had a prior arrest than one arrested for arson, sex offenses, homicide, or driving while intoxicated. Calculations based upon statistical matter found in Volume XI of the Uniform Crime -Reports discloses 
felony," ${ }^{215}$ or "crimes involving moral turpitude" 216 in the terms of the ordinances clearly demonstrates the failure to give this factor any consideration. The choice of crimes included in many of the ordinances often appears illogical and arbitrary when considered with respect to the stated objective. $^{217}$ The same may be said in reference to the time when the prior conviction must have occurred. ${ }^{218}$ In regard to persons who have demonstrated their rehabilitation, only those who enter the jurisdiction after a certain period are exempted from the ordinance. ${ }^{219}$ It seems irrational that registered persons, after rehabilitation, must be subjected to the burdens for the rest of their lives, while individuals entering the jurisdiction after a certain period are completely exempted. Surely, the danger to the community cannot be predicated upon the mere fortuitous circumstance of when an individual first enters the jurisdiction.

But even assuming that the theory of these ordinances is valid and that they were drafted to reflect the considerations stated above, the actual practices show that the theory is merely the facade for police harassment of individuals who have been convicted of a crime. ${ }^{220}$ This study has indicated that in some jurisdictions the number of persons registering is substantial, 221 while in others a definite policy of non-publicity and nonenforcement appears to be followed. ${ }^{222}$ In fact, one authoritative source stated that the strength of these laws lies in the fact that persons required to register will not do so. ${ }^{223}$ However, the ordinances also provide a

the following data with respect to the number of persons arrested for specific offenses in 1940 who had records of prior convictions for similar offenses.

Offense

Narcotic Offenses

Burglary

Larceny

Forgery \& Counterfeiting

Embezzlement \& Fraud

Auto Theft

Driving While Intoxicated

Rape

Homicide

214. See text preceding note 39 supra.

215. See text at note 39 and note 39 supra.

216. See text at note 40 and note 40 supra.

217. E.g., see text following note 41 supra.

218. See text at note 69 et seq. supra.

219. Ibid.

220. See text at notes 15 and 169 et seq. supra. In Meyer v. Nebraska, 262 U.S. $390,399-400$ (1923), the Court stated: "The established doctrine is that this liberty [under due process] may not be interfered with, under the guise of protecting the public interest, by legislative action which is arbitrary or without reasonable relation to some purpose within the competency of the State to effect [personal liberty]." See also Liggett Co. v. Baldridge, 278 U.S. 105, 113 (1928) (economic regulation). But cf. Daniel v. Family Insurance Co., 336 U.S. 220, 225 (1949) (economic regulation).

221. See Appendix C infra.

222. See Appendix C infra; see text at notes 19, 133 et seq. supra.

223. See note 17 supra.
Per Cent of Persons Similar Prior Convictions

20.0

10.9

10.4

8.3

5.6

5.0

0.8 
method for possible police harassment of registered persons. ${ }^{224}$ It is questionable whether the registration of these persons, even where a substantial number have registered, materially aids the police in preventing criminality or apprehending criminals. The practices observed lead to the conclusion that the registration data is rarely used by the police. ${ }^{225}$ In Philadelphia, the general practice of the police is to place the data in regular police criminal identification files. Although the fingerprints are classified and are available for comparison with prints at the scene of a crime, the police can probably make a quicker check by forwarding the prints to the FBI, since any prints obtained by the local police through registration would also be on file with the FBI. ${ }^{226}$ The criminal registration laws do enable the police to secure a recent photograph of persons in the locality, 227 and the police can use this to identify persons who have been engaged in criminal acts. This is probably the greatest and most useful attribute of the criminal registration laws, but it is doubtful whether this attribute is sufficient, in view of the other considerations, to hold these laws either socially desirable or constitutional. This study has shown that in a large city the registration information may get lost in the mass of police records and that no attempt is made to advise the law enforcement officials who will come in contact with the registrant that they are to keep a particularly close watch on him because of his prior criminal record; however, it is quite possible, especially in smaller towns, that the fact that a person with a prior criminal record is in the locality would be spread rapidly to the entire police force, and indeed, the registrant might well be singled out for "special treatment." The social desirability of such special observation and treatment is a matter of opinion. Police claim that these ordinances provide them with information as to where and for whom to look when there is trouble, and further that a person who knows that he is being observed will keep out of trouble. To a certain degree the latter is the theory upon which parole and probation are based. But it is equally true that police knowledge of a prior criminal record can result in constant harassment of an individual when-

224. Compare text at note 163 et seq. supra with text at note 169 et seq. supra. 225. See text at note 155 et seq. sichra.

226. See text at note 154 et seq. supra.

227. Many police departments in communications to the Law Review considered this aspect of the ordinance particularly important. One department (Allentown) enclosed a photograph of a registrant at the time of his registration after release from prison (Age 25) and a photograph taken 5I/2 years previously at the time of his arrest. A comparison of the photographs revealed that it is quite possible that someone could identify the individual by the later photograph and not by the former. The Philadelphia police have recently begun taking palm prints of registrants who have a prior record involving burglary, robbery, and similar crimes. These prints can be useful for identification of prints found at the scene of a crime.

Prior to the 1936 Democratic National Convention in Philadelphia the Philadelphia police with cooperation from police departments all over the country, made up a thirteen volume album of 10,000 photos of pickpockets, hotel thieves, confidence men, gamblers and other known criminals to be used by the police in identifying undesirables. N.Y. Times, June 17, 1936, p. 2, col. 4. Several hundred of these photographs were shown to hotel detectives and floor managers prior to the convention. N.Y. Times, June 19, 1936, p. 8, col. 4. 
ever any criminal act occurs in the locality. Such harassment usually will result in a great number of arrests without sufficient probable cause. ${ }^{228}$ In view of the fact that access to the registration information is not restricted in some instances, ${ }^{229}$ this type of harassment may be carried over into areas where the individual's opportunity to secure employment would be seriously hampered.

In other jurisdictions the possible benefit that might be derived from a person's registration is sacrificed by following a policy of not publicizing the existence of these ordinances and not encouraging persons to register. ${ }^{230}$ The fact that the police can arrest an individual for failure to comply with the ordinance permits" them to detain him on "suspicion" for purposes of investigation with respect to a more serious crime for which they have no evidence to hold him. ${ }^{231}$ Local authorities also use the ordinance to expel "undesirables" from the jurisdiction by suspending sentence upon condition that they leave town. ${ }^{232}$ It has also been stated that the ordinances are used to force cooperation from individuals who have failed to register by threatening prosecution for violating the ordinances. ${ }^{233}$ Persons unadvised of the existence of such ordinances may become, in effect, "police bait." They may be incarcerated whenever the police feel that they should be kept off the streets. The pattern of selective prosecution which was discerned in some communities enables local authorities to use the ordinances as an additional effective harassing weapon. ${ }^{234}$ It is significant that none of the ordinances require a "willful" failure to register to constitute a violation. ${ }^{235}$ If the purpose of these ordinances is to secure

228. One symptom of this "special treatment" is the periodic mass arrest of known criminals engaged in by some police departments, possibly for the political purpose of informing the citizens that something is being done about crime. For example, immediately prior to the 1936 National Convention of the Democratic Party in Philadelphia, Philadelphia's Mayor Wilson ordered Superintendent of Police Malone to arrest every known criminal in the city. N.Y. Times, June 17, 1936 , p. 2 , col. 4.

The police practice of "round-ups" is too well known to need further discussion.

229. See text at note 121 et seq. supra.

230. See text following note 133 supra.

231. See text following note 166 supra and text at note 175 et seq. supra.

232. See Appendix D infra and text at 170 et seq. supra.

The constitutionality of this sort of banishment is open to question. It has been held contrary to public policy to permit one state to "dump" their undesirables on another. See, e.g., People v. Baum, 251 Mich. 187, 231 N.W. 95 (1930). In In re Scarborough, 76 Cal. App.2d 648, 650, 173 P.2d 825, 827 (1946) it was stated that the "[s] ame principle which prohibits the banishment of a criminal from a state or from the United States applies with equal force to a county or city." See also, Comment, 31 Minn. L. Rev. 742 (1947).

233. A few Philadephia detectives stated that they had employed this method of obtaining information from uncooperative individuals. The threat of prosecution is made more effective by exaggerating to an individual the available penalties under the ordinance.

234. See text following note 169 supra.

235. Compare the Alien Registration Act, 66 Stat. 225 (1952), 8 U.S.C. § 1306 (1952) ("Any alien required to apply for registration.. who willfully fails or refuses to make such application . . shall be guilty of a misdemeanor. . .) (italics added), and the Universal Military Training Act, 62 Stat. 622 (1948), 50 U.S.C. App. \$462 (1952) (knowingly fail to register). See also 86 ConG. REC. 8346 (1940) (Senate discussion of meaning of willful in Alien Registration Act). 
the registration and identification of criminally dangerous persons, the penalty should only be severe enough to insure compliance with the registration provision, and should be imposed only against those who willfully fail to register; also, there should be provisions for publicizing the existence of registration obligations. The failure to incorporate such provisions tends to prove that the stated objective is merely a verbal justification, while the true objective is to provide the police with a weapon to harass individuals simply because they have been previously convicted of a crime.

The use of these ordinances to harass selective cases as the whims of the police dictate, raises a serious constitutional question. In 1886 the Supreme Court of the United States declared that even though a law is not discriminatory upon its face, if the evidence of practices under that law indicates a history of discriminatory application, the law violates equal protection. ${ }^{236}$ Applying this test to the criminal registration laws there is a great probability that this situation prevails. ${ }^{237}$ The constant use of the ordinances to prosecute those in violation would, in itself, be an advertisement of their existence and tend to destroy their effectiveness as a harassment weapon.

This Note has not attempted to point out all the factors involved in determining the question of social desirability or to point out all the constitutional questions. Enough has been said, however, to raise serious doubts on both scores. Other questions of social desirability are also present in these laws, such as their effect upon those individuals sincerely attempting to rehabilitate themselves and to be accepted back into society as useful members. Having ostensibly paid their debt to society for their prior crime, is it socially desirable to stigmatize these individuals further with marks of their past errors by requiring them to carry criminal registration cards and to report all subsequent changes of address to the police? Likewise, other constitutional objections may be inherent in these laws. For example, a question of vagueness and indefiniteness may be involved in some of these ordinances, both in terms of who are included and for what duration..$^{238}$ In addition, some of these ordinances may be inflicting an unconstitutional burden upon interstate commerce. ${ }^{239}$ The possibility cannot be overlooked that even though no one aspect may render

236. Yick Wo v. Hopkins, 118 U.S. 356 (1886) ; Norris v. Alabama, 294 U.S. 587 (1935); Dahnke-Walker Milling Co. v. Bondurant, 257 U.S. 282 (1921).

237. See text at notes $166-80$ supra.

238. See, e.g., Lanzetta v. New Jersey, 306 U.S. 451 (1939); Winters v. New York, 331 U.S. 507 (1948). The vagueness of the statutes is exemplified in the text preceding note 36 and the text at notes 50 and 74 supra. See also text following note 187 supra.

239. See Edwards v. California, 314 U.S. 160 (1941); note 195 supra. For example, under the newly-proposed Camden, New Jersey ordinance, which requires registration immediately upon entering the city, an individual could not even pass through the city on a public carrier without interrupting his journey to register. See note 76 supra. 
these ordinances unconstitutional under the due process clause, invalidation may result because the basic principles, content, and administration of these ordinances combine to offend against "a sense of justice" inherent in American democracy. ${ }^{240}$ The imposition of the registration requirements upon persons merely because they have been convicted of a single "crime," the fact that persons in some cases are subjected to the registration requirements for the rest of their lives, and especially the manner in which these laws are used leads to the conclusion that these ordinances are socially undesirable and of questionable constitutionality:

240. This test of constitutionality has been enunciated recently by the Supreme Court. In Rochin v. California, 342 U.S. 165 (1952), the Court struck down a conviction for violating a state law forbidding possession of morphine where evidence was obtained by the forcible use of a stomach pump on the defendant. The basis of the majority opinion was that due process of law will not allow any conviction "brought about by methods that offend a 'sense of justice." Id. at 173. The Court has also recognized that this principle applies to legislation. In Galdan v. Press, 347 U.S. 522 (1954), the validity of Section 22 of the Internal Security Act of 1950, providing for the deportation of any alien who has been a member of the Communist Party, was in issue. Sustaining the act under Congress' broad power over aliens, the Court pointed out: "If due process bars Congress from enactments that shock the sense of fair play-which is the essence of due process-one is entitled to ask whether it is not beyond the power of Congress to deport an alien who was duped into joining the Communist Party. . . ." Id. at 530 . 


\section{APPENDIX A}

Distribution of Cities Surveyed to Determine Whether or Not They Have Enacted Criminal Registration Ordinances: According to Population Groups 1

\begin{tabular}{|c|c|c|c|c|c|c|}
\hline $\begin{array}{l}\text { Population } \\
\text { Group- } \\
\text { 1950 Census }\end{array}$ & $\begin{array}{l}\text { Number } \\
\text { of Cities } \\
\text { in Group }\end{array}$ & $\begin{array}{l}\text { Number } \\
\text { of Cities } \\
\text { Surveyed }\end{array}$ & $\begin{array}{l}\text { Number and } \\
\text { Percentage } \\
\text { Responding }\end{array}$ & $\begin{array}{l}\text { Number } \\
\text { Responding } \\
\text { Having } \\
\text { Enacted } \\
\text { Ordinances }\end{array}$ & $\begin{array}{c}\text { Number } \\
\text { Responding } \\
\text { Not } \\
\text { Having } \\
\text { Enacted } \\
\text { Ordinances }\end{array}$ & $\begin{array}{c}\text { Percentage } \\
\text { of Cities } \\
\text { Surveyed } \\
\text { Responding } \\
\text { Having } \\
\text { Enacted } \\
\text { Ordinances }\end{array}$ \\
\hline $\begin{array}{c}\text { Over } 1 \\
\text { million }\end{array}$ & 5 & 5 & $5(100 \%)$ & 2 & 3 & $40.0 \%$ \\
\hline $\begin{array}{l}500,000 \text { to } \\
1 \text { million }\end{array}$ & 13 & 13 & $13(100 \%)$ & 2 & 11 & $15.4 \%$ \\
\hline $\begin{array}{l}250,000 \text { to } \\
500,000\end{array}$ & 23 & 23 & $22(96 \%)$ & 9 & 13 & $41.0 \%$ \\
\hline $\begin{array}{l}100,000 \text { to } \\
250,000\end{array}$ & 65 & 65 & $47(72 \%)$ & 11 & 36 & $23.4 \%$ \\
\hline $\begin{array}{l}50,000 \text { to } \\
100,000\end{array}$ & 126 & 126 & $68(54 \%)$ & 8 & 60 & $11.8 \%$ \\
\hline $\begin{array}{l}25,000 \text { to } \\
50,000\end{array}$ & 252 & $168^{3}$ & $86(51 \%)$ & 11 & 75 & $12.8 \%$ \\
\hline $\begin{array}{l}10,000 \text { to }^{4} \\
25,000\end{array}$ & 778 & 5 & $5(100 \%)$ & 5 & 0 & - \\
\hline $\begin{array}{l}\text { less than } 4 \\
10,000\end{array}$ & - & 1 & $1(100 \%)$ & 1 & 0 & 一 \\
\hline
\end{tabular}

1. This survey was made between August, 1953 and March, 1954.

2. It has been impossible to determine whether a city having an ordinance would be more or less likely to respond.

3. A few cities in this group were surveyed as a result of information from other cities indicating that they had ordinances.

4. The data for these groups is not statistically significant. 


\section{APPENDIX B}

\section{Localities Which Haye Enacted Ordinances}

Locality

Akron, Ohio

Allentown, $\mathrm{Pa}$.

Arcadia, Cal.

Atlantic City, N. J.

*Beverly Hills, Cal.

Birmingham, Ala.

Camden, N. J.

Canton, Ohio

Cincinnati, Ohio

Collingswood, N. J.

Columbus, Ohio

Coral Gables, Fla.

Evansville, Ind.

Fort Lauderdale, Fla.

*Gadsden, Ala.

Harrisburg, $\mathrm{Pa}$.

Hot Springs, Ark.

Jersey City, N. J.

Lakeland, Fla.

Lakewood, N. J.

Las Vegas, Nev.

Long Beach, Cal.

Lorain, Ohio

Los Angeles, Cal.

Louisville, Ky.

\begin{tabular}{r}
\multicolumn{1}{c}{ Date } \\
1938 \\
$2 / 14 / 50$ \\
$12 / 5 / 33$ \\
$4 / 11 / 35$ \\
\hline \\
\hline $6 / 14 / 34$ \\
\hline $3 / 26 / 52$ \\
$6 / 4 / 45$ \\
$4 / 21 / 52$ \\
$12 / 19 / 33$ \\
1953 \\
\hline \\
\hline $8 / 24 / 37$ \\
$8 / 1 / 46$ \\
$5 / 6 / 52$ \\
$7 / 21 / 53$ \\
$11 / 11 / 51$ \\
$6 / 22 / 45$ \\
\hline $4 / 16 / 51$ \\
$9 / 12 / 33$ \\
$7 / 14 / 37$
\end{tabular}

Locality

Miami, Fla.

Miami Beach, Fla.

Norfolk, Va.

Pasadena, Cal.

Pensacola, Fla.

Philadelphia, Pa.

Phoenix, Ariz.

Reno, Nev.

Rochester, Minn.

St. Paul, Minn.

St. Petersburg, Fla.

San Diego, Cal.

*San Francisco, Cal.

San Jose, Cal.

* Santa Ana, Cal.

Seattle, Wash.

Shaker Heights, Ohio

South Gate, Cal.

*South St. Paul, Minn.

Springfield, Ohio

*Tampa, Fla. ${ }^{1}$

Trenton, N. J.

Tulsa, Okla.

*West Palm Beach, Fla.2
Date

9/ $2 / 36$

$11 / 17 / 33$

$11 / 25 / 48$

$3 / 16 / 37$

3/ $8 / 48$

$2 / 15 / 36$

11/ $3 / 41$

$1 / 29 / 36$

1/ $7 / 41$

$7 / 20 / 36$

7/ $3 / 45$

$9 / 26 / 33$

$11 / 14 / 43$

1945

* Copies of ordinances not obtained from these cities.

1. Ordinance no longer in effect having expired of its own limitation.

2. Ordinance declared invalid by a municipal judge. 


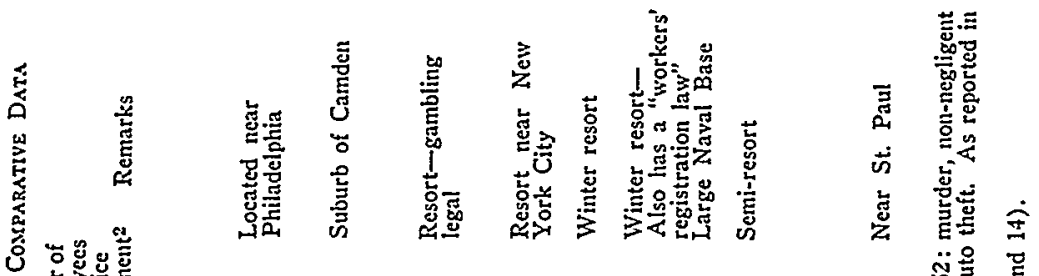

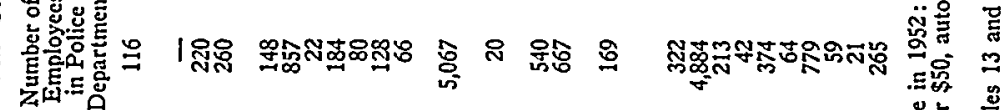

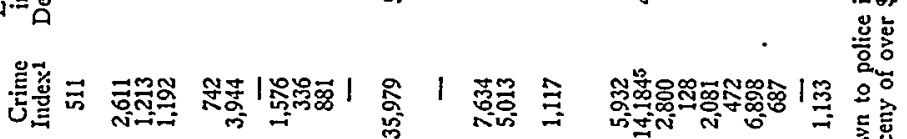
푱

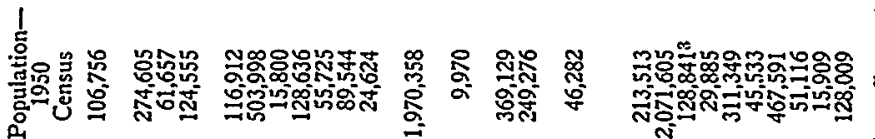
品范

茄总

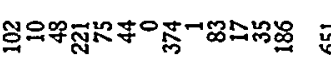

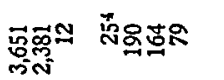

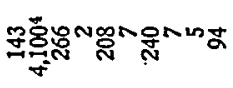

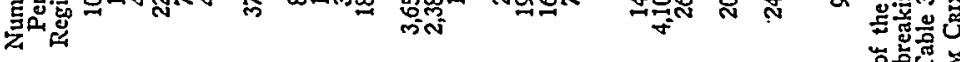
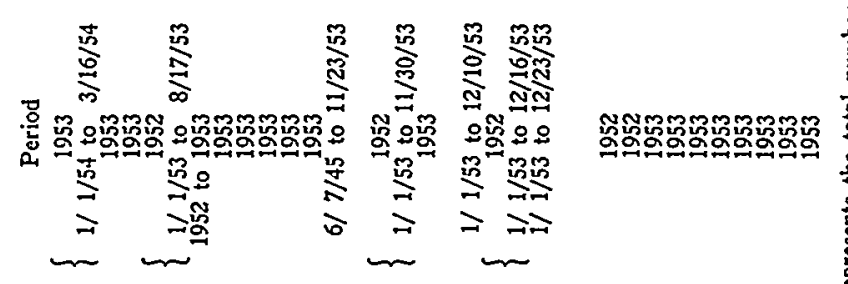

然

总

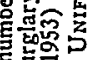

起部

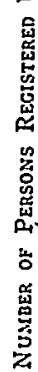

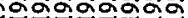

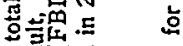

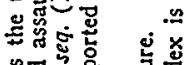




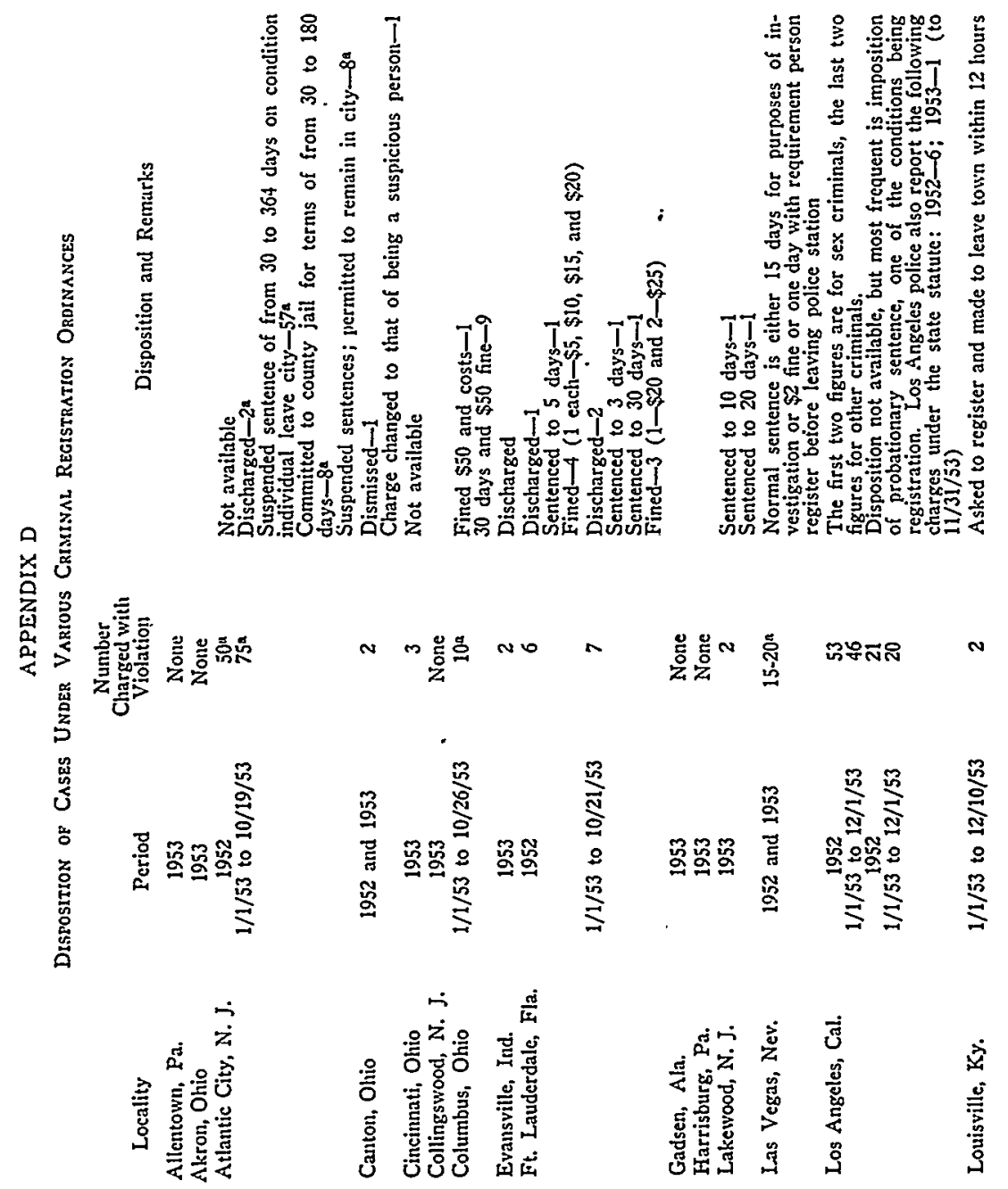




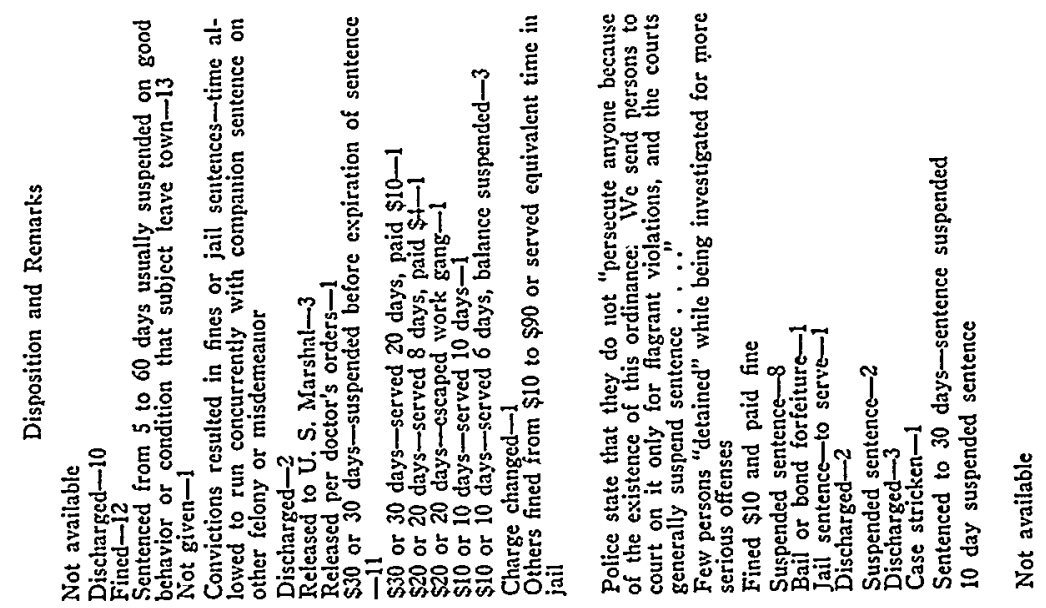

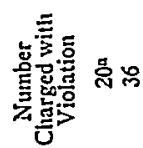

ล ถ็

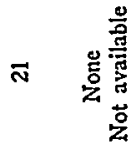

总 $\rightarrow$

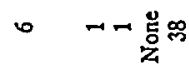

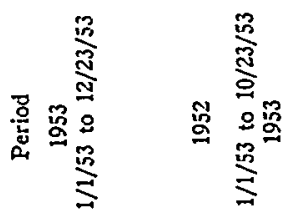

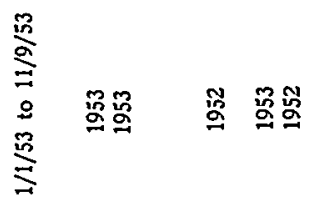

容 突

\&

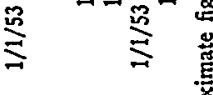

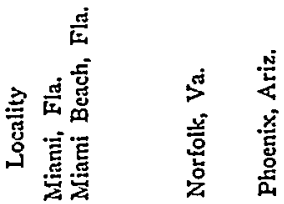

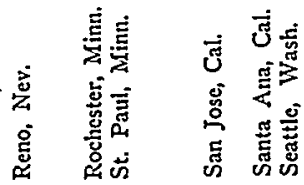

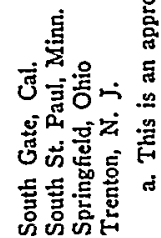




\section{APPENDIX E}

Cases in Philadelphia in Which a Criminal Registration Violation Was Lodged in Conjunction With Some Other Offense 1

Total cases in which persons were charged with violating ordinance $\ldots \ldots \ldots \ldots, 692$

Cases in which only charge was violation of ordinance $\ldots \ldots \ldots \ldots \ldots \ldots \ldots .19$

Cases in which violation of the ordinance was lodged in conjunction with some

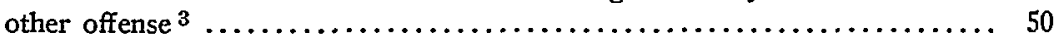

The Other Charges: 4

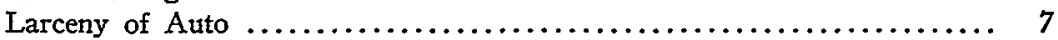

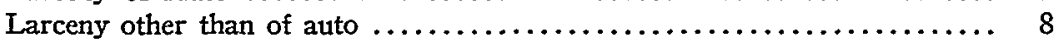

Burglary ................................................. 6

Disorderly Conduct $\ldots \ldots \ldots \ldots \ldots \ldots \ldots \ldots \ldots \ldots \ldots \ldots \ldots \ldots, 4$

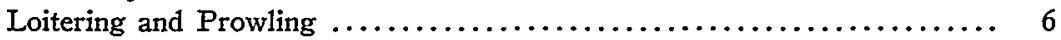

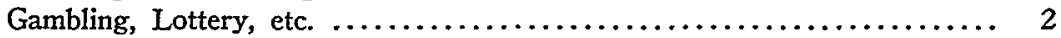

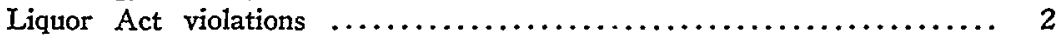

A.W.O.L. from military service $\ldots \ldots \ldots \ldots \ldots \ldots \ldots \ldots \ldots \ldots \ldots \ldots, 1$

Attempted Breaking \& Entering \& Carrying Concealed Deadly Weapon ... 1

Assault and Battery \& Carrying Concealed Deadly Weapon ............ 1

Assault and Battery $\ldots \ldots \ldots \ldots \ldots \ldots \ldots \ldots \ldots \ldots \ldots \ldots \ldots \ldots, 1$

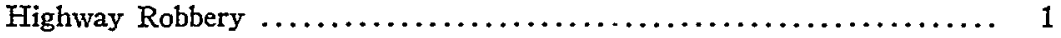

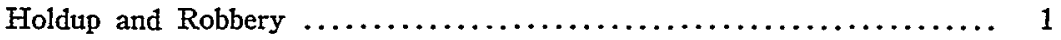

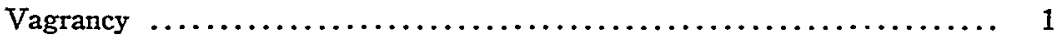

Rape, Sodomy, Assault \& Battery, Larceny of Auto, Robbery, Leaving scene of accident, No drivers license ........................... 1

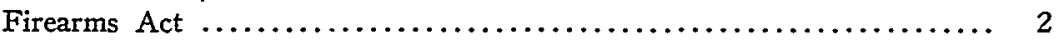

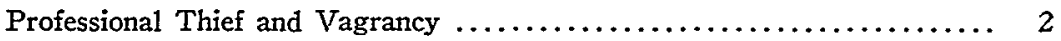

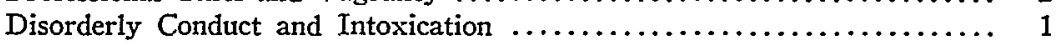

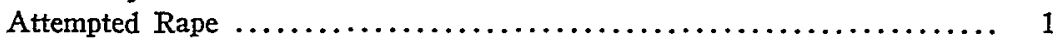

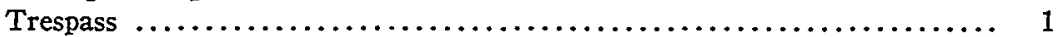

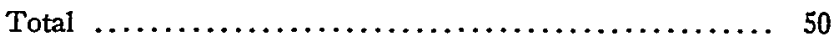

1. During the first nine months of 1953.

2. Only 68 persons were charged, one person being charged with a violation on two different occasions.

3. In a few cases the suspect was charged with an offense apparently known as "investigation," the existence of which can not be found in Pennsylvania law. Therefore, such charges have not been included in this tabulation.

4. In most cases in which more than one charge was lodged only the most serious one was listed. 